\title{
LA BASÍLICA-SINAGOGA DE L'ALCÚDIA D'ELX (1905-2005). PROBLEMES I ESTAT DE LA QÜESTIÓ 100 ANYS DESPRÉS ${ }^{1}$
}

\author{
ROBERTO LORENZO DE SAN ROMÁN
}

\begin{abstract}
Tractarem aci de l'edifici de la basílica-sinagoga d'//ici, descobert el 1905 i present a moltes de les publicacions dedicades al paleocristianisme hispànic des de llavors ençà. N'analitzarem els processos del descobriment i les excavacions, les característiques constructives i les principals troballes efectuades. Però també parlarem de les inscripcions gregues del mosaic policrom, mostrarem novetats pel que fa a la necròpolis ad sanctos immediata a la basílica, i algunes consideracions envers l'antic debat pel caràcter jueu o cristià de l'edifici. Finalment ens centrarem en criticar l'última -i massa reculada-datació fundacional, aixi com en defensar-ne una altra possibilitat, ja suggerida d'antic.
\end{abstract}

In this article we will discuss the basilica-synagogue of /lici discovered in 1905, which has appeared in many publications on Spanish paleochristianity since then. We will analyse its discovery and excavation, the construction characteristics and the main finds that have been made. We also will talk about the Greek polychrome mosaic inscriptions, present the new discoveries relating to the ad sanctos necropolis next to the basilica, and add our comments to the perennial debate about the Jewish or Christian character of the building. Finally we will question the most recent -and in our opinion excessively early - foundation date, and defend an alternative one, suggested long ago

\begin{abstract}
"[...] hay que proceder a una publicación a fondo de los materiales básicos, que a menudo se arrastran por la bibliografia sin que se les haya dedicado una monografía sistemática y a fondo. En este sentido me parece de excepcional importancia la publicación de la sinagoga basilica de Elche y sus mosaicos en forma completa, ya que algunas de las publicaciones generales sobre ella fantasean un tanto en la disposición y el diseño de los mismos."

Enric A. Llobregat $(1985,447)$.
\end{abstract}

\section{EL DESCOBRIMENT I LES EXCAVACIONS}

El juliol del 1905, al ja ben conegut a Europa jaciment de l'Alcúdia, ubicat al terme municipal d'Elx (Alacant) -i des de l'any 1996 propietat de la Universitat d'Alacant-, començà una campanya d'excavacions que en principi havien de dur a terme els investigadors Pierre Paris i Artur Engel, però que finalment va dirigirla només Pierre Paris, catedràtic d'arqueologia i història de l'art en la Universitat de Burdeos. L'excavació es plantejà com una línia diagonal que anés des de l'anomenada muralla i la zona de termes ja excavades per Pere Ibarra el 1890 (Ibarra, 1889; Ibarra Ruíz, 1926, 186) fins al punt en què va aparèixer la Dama d'Elx el 1897. Però va desenvolupar-se'n amb escassos resultats, en bona part deguts a la "pertinaz calentura" que sorprengué Pierre Paris a l'agost, obligant-lo a marxar. Per això fou el seu jove adjunt Eugène Albertini qui va continuar-les, avançant cap a l'oest, i qui va documentar-hi una sèrie d'estructures (Albertini, 1906b; 1907)

\footnotetext{
- El present article és un avanç dels diferents problemes que recentment hem detectat, i de les principals conclusions a què hem pogut arribar, sobre les problemàtiques que-des de fa pràcticament un segle- envolten aquest desconegut edifici de l'Alcúdia, pareix que definitivament interpretat com a basílica cristiana. Els més ressenyables resultats, pel que fa a la basílica, d'eixe treball-memòria de llicenciatura inèdita dirigida per la Dra. Sònia Gutiérrez Lloret-, els presentem ara per tal de facilitar a la comunitat investigadora un millor accés a la informació coneguda d'aquest important i desconegut edifici. Ara bé, en aquest treball no tractarem sinó marginalment de l'arribada del cristianisme com a religió oriental a la ciutat d'//ici, ni del fet religiós o del naixement $i$ consolidació de les seues primeres comunitats cristianes, temes dels quals pràcticament res no pot dir-se a l'estat actual de la investigació Altrament, per qüestions d'espai, l'evolució diacrònica de la basílica i la seua contextualitzacié dins els esdeveniments propis de la ciutat i de la zona del sud-est en època tardana -el problema de les seus episcopals, especialment-, són temes als quals estem aprofundint $i$ que deixem per a un altre moment, emplaçant al lector interessat, per ara, a la ja esmentada anàlisi historiogràfica i estat de la qüestió (Lorenzo, e.p., amb bibliografia comentada).
} 
fins que el 8 d'agost l'arxiver i arqueòleg d'Elx Pere Ibarra -erudita figura local imprescindible pel que fa a la investigació d'Elx i de l'Alcúdia (Castaño, 2002)-de visita pel jaciment comprovà amb gran desolació els escassos resultats obtinguts ${ }^{2}$, i li va aconsellar d'excavar "donde años atrás la azada había señalado la presencia de un mosaico al plantar una higuera" (Ibarra Ruiz, 1906, 120).

Centrant els seus esforços a una nova zona, l'11 d'agost ja identificava Eugène Albertini una basílica ${ }^{3}$, que va provocar la lògica i conseqüent emoció de Pierre Paris en conèixer la notícia del que varen considerar el més important descobriment efectuat a la lloma, o turó de L'Alcúdia 4 .

Pere Ibarra comunicà de seguida a la Revista de la Asociación Artístico-Arqueológica Barcelonesa -n'era soci corresponent a Elx des del gener del 1897-el descobriment de la que ja consideraven basilica d'llici, amb un to que reflecteix no només la il-lusió i satisfacció de l'investigador, sinó també la preocupació per un jaciment i una tasca que, per les experiències de son germà Aurelià, ja coneixia com a poc emparada per les autoritats. La menció (Ibarra Ruíz, 1905), publicada el mateix any del descobriment, anava acompanyada d'unes fotografies de conjunt $i$, de seguida, va ampliar la investigació amb una molt més elaborada publicació al Boletín de la Real Academia de la Historia (Ibarra Ruíz, 1906) seria acadèmic corresponent per la Província d'Alacant des del febrer de 1915-, amb la descripció completa tant de l'edifici com del sorprenent mosaic que pavimentava bona part del terra de l'estructura excavada. De seguida també varen veure la llum els estudis d'Eugène Albertini (1906a) -l'autèntic responsable de les excavacions- als Comptes rendus de l'Académie des Inscriptions i, més elaborats (Albertini, 1906b; 1907), al Bulletin Hispanique -on també va publicar Pierre Paris (1907); que n'era el director-. La principal conseqüència d'aquest estudi del 1907 fou que Eugène Albertini canviés la seua impressió inicial (1906a), i presentés ara l'edifici com una sinagoga.

Aixi doncs, com a resum d'aquestes excavacions $\mathrm{i}$ investigacions de 1905 , tenim que Pere Ibarra (1906) i Eugène Albertini (1906b; 1907) varen mostrar un edifici quadrangular, excavat en superfície a partir del mosaic ja delimitat, amb un absis a l'est que, no pavimentat pel mosaic, Pere Ibarra (1906, 121) va manar d'excavar-lo baixant el nivell del terra fins a trobar restes d'allò que va interpretar com l'altar de la basílica; "una basa ática en piedra de cantería, y dos sillares sueltos". Al temps, a la zona que anomena de l'epístola -a l'esquerra de l'absis cantó sud-est-, Pere Ibarra desmuntà el que semblaven escalons pensant que el mosaic estaria per sota, però en no aparèixer va pensar que res no es conservava del paviment en aquella zona. A més de constatar una sèrie de reparacions al mosaic el centre de l'interès d'aquests investigadors-, Pere Ibarra $(1906,122)$ va fer menció de la cementació conservada de les parets dels costats nord i oest, quedant el sud sense excavar, mentre que per a l'est, on es trobava l'absis, no va constatar cap cementació al costat del mosaic, que acabava "en arista viva, sin barrón alguno ó cadena que lo cierre". És en aquest lloc on, precisament per no haver-hi mosaic, va continuar l'excavació Pere Ibarra (1906, 125), comprovant l'existència d'un sòl d'argamassa separat del paviment $25 \mathrm{~cm}$, segons ell per tal de "solidificar su asiento", mentre que al nivell del pis es trobaven barrejats fragments de ceràmica ibèrica amb els "detritus inferiores". D'altra banda, cap a l'est del mosaic constatà que l'absis no recolzava els seus extrems al paviment, excepte pel sud (Ibarra Ruíz, 1906, 126), i que el muret de 60 $\mathrm{cm}$ que el formava estava realitzat amb materials d'enderroc i sense arrebossar. Darrere d'ell hi havia tangent una paret de nord a sud, i més enllà "una solera de hormigón grueso, indefinida. Después... tierras inexploradas".

Aquest sistema de descripció i excavació, que actualment podria parèixer insuficient, hem d'emmarcar-ho com pertanyent a uns erudits de principis del S.XX que no coneixien l'excavació en obert i pràcticament es basaven

\footnotetext{
2 1905, Agost, 8. Efeméride 491. "Mi visita a la Alcúdia", "Noticia de la excavación de Albertini" (AHME,70-B-030.000). (Vid. A.Ramos, 1952; 1974, 78-85, qui transcriu les Efemérides inèdites i perdudes de Pere lbarra).

3 1905, Agost, 11. Efeméride 492. "Basílica" "Copiar todas las notas al poner en limpio esta parte del estudio", "Copiar también toda esta nota del descubrimiento de la Basilica" (AHME, 70-B-030.000).

4 1905, Agost, 28. Efeméride 499. "Hemos tenido (Pepito López) carta contestación de don Pedro Paris. Su estado de salud no es satisfactorio. Hubo de marcharse de aquí antes de hora, molestado por pertinaz calentura. Dice que el hallazgo del mosaico cristiano de la loma es indudablemente, el descubrimiento más importante que se ha realizado en la Alcúdia. Desea con ansia restablecerse para ir a París, en donde organizar trabajos que nos conduzcan al deseado fin de descubrir toda la loma..." (AHME, 70-B-030.000).
} 


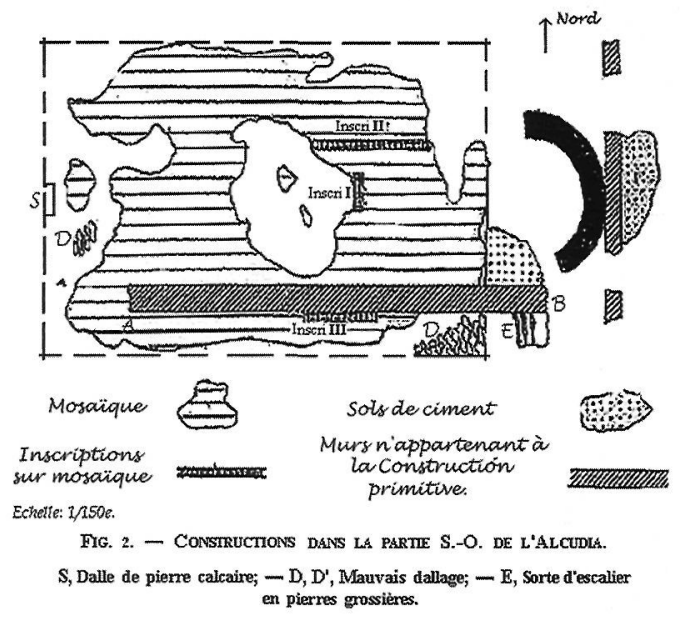

Figura 1: Planta de la basílica d'llici segons Eugène Albertini (1906b,337).

a seguir un sondeig que els mostrara estructures que calia buidar de terra; i per açò l'edifici va romandre tants i tants anys sense estar degudament delimitat, per no relacionarse clarament el mosaic amb els murs de la basílica, especialment desconeguda als seus costats est i sud.

Allò mateix ho trobem en l'informe que publicà Eugène Albertini (1906b; 1907), al qual, i després de referir-se als edificis excavats per ell, d'analitzar la ceràmica ibèrica apareguda a la campanya i de reflexionar sobre el jaciment en conjunt -i quan ja coneixia el que opinava sobre l'edifici Pere Ibarra en 1905-, ens precisa la informació que en aquell moment també presentava Pere Ibarra, amb més dades que aquest no menciona al seu informe, $i$ incloenthi a més la planta de l'edifici que recuperem a continuació (Fig. 1).

Eugène Albertini (1907) informa que, descobert el mosaic, buidà de terra tota la seua superfície; un gran paquet de terres d'1 m d'espessor on es va trobar "un grand nombre de débris architecturaux en pierre du pays", destacant tres fragments de capitells corintis, un d'ells amb $38 \mathrm{~cm}$ d'altura conservada, dos fragments de volutes i un timbal de columna no estriada, malgrat que el més nombrós varen ser petits fragments de superfícies generalment planes de contorns retallats i decorats amb línies en creu, que encaixà fàcilment obtenint un enreixat de pedra que va suposar una finestra de factura aràbiga.

D'aquesta manera excavà el mosaic fins que va aparèixer sencer $i$ amb forma de rectangle. Ampliant cap a l'oest va trobar-se un sial de pedra calcària de $135 \times 50 \mathrm{~cm}$ al final del paviment, i, fent-ho cap a l'est, l'absis separat 1 metre del mosaic a la part nord $-i$, a diferència de Pere Ibarra, també separat $2 \mathrm{~m}$ a la part sud, amb $58 \mathrm{~cm}$ d'amplària de mur, 1'50 d'arc intern i 2'10 d'arc extern, respecte del mosaic-. Eugène Albertini indica expressament $(1907,126)$ "de toute évidence" que la terra ubicada entre el mosaic i l'absis havia estat remoguda "depuis l'époque antique", atès que va trobar-se una important acumulació de pedres bastes que hi devien haver sigut Ilançades de propòsit. Únicament més avall, escriu, a $1 \mathrm{~m}$ aproximadament per sota del mosaic, l'estratigrafia recobrava el seu "aspect naturel", amb ceràmica ibèrica i restes d'osseres d'animals. L'absis es conservava a una alçària màxima d'1 m i, igual que la zona del voltant, apareixia $10 \mathrm{~cm}$ més baix que el mosaic -n'aflorà "avant la fouille, à 0'10 m au-dessous du sol"-. Aspecte interessant que Pere Ibarra no menciona, tot i que Eugène Albertini sí que va coincidir amb ell en la descripció del mur, un "appareil médiocre, sans revêtement d'aucune sorte".

En el procés de delimitació de la superfície del paviment, i com a un altre punt que tampoc no va mencionar-ne Pere Ibarra, Eugène Albertini $(1907,121)$ ens transmet l'existència d'un mur d'aparença bastant irregular, de $60 \mathrm{~cm}$ d'amplària i conservat entre els 30 i els $85 \mathrm{~cm}$ d'alçària, que cobria el mosaic amb una perfecta direcció oest-est, sobrepassant-lo fins arribar a $50 \mathrm{~cm}$ del mur de l'absis, i flanquejat en eixa part final per "des pierres brutes, qui paraissaient disposées de façon à former trois marches d'escalier, hautes en tout de 0'75 m" pel sud, i per un terra de "sol cimenté" al nord, a un nivell $10 \mathrm{~cm}$ per sota el mosaic, "sous laquelle il semble d'ailleurs se prolonger". Aquest mur va ser desmuntat, segons l'autor, per trobar-se clarament per damunt del mosaic, i pràcticament és l'única relació estratigràfica clara que hui dia tenim de les existents entre els diferents murs $\mathrm{i}$ el paviment. També comenta com, més cap a l'est, l'excavació va trobar un altre mur tangent per darrere de l'absis, però "un peu moins haut qu'elle, et de construction très mauvaise", i amb què es relacionava un fragment de paviment "en ciment grossier, à un niveau légèrement supérieur au niveau de la mosaïque".

Açò és el que coneixem pel que fa a les dades tècniques d'excavació. Però quan a penes havien començat els estudis sobre el mosaic, l'edifici i el seu entorn, l'espoli brutal a què es va veure sotmès el paviment -pels 


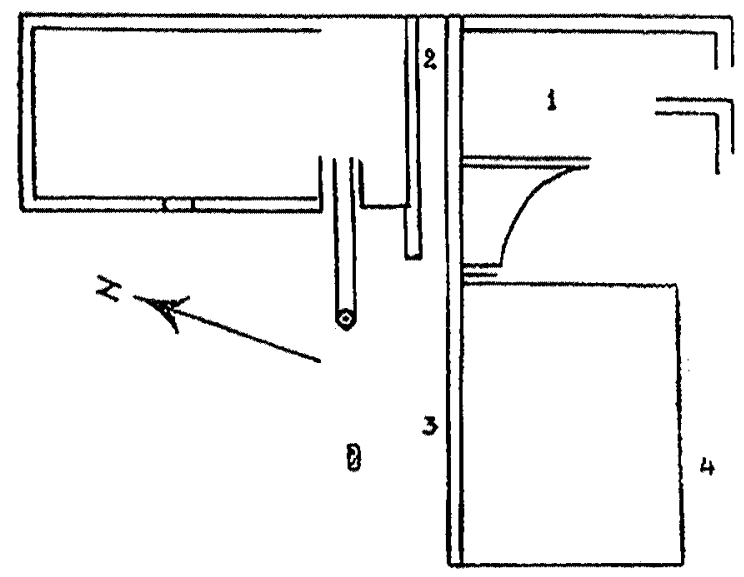

Figura 2: Planta de la Basílica, i estructures relacionades, d'Alejandro Ramos $(1955,131)$.

visitants que s'emportaven les tessellae com a record-obligà al seu cobriment el 6 de setembre de 1907 per tal d'evitar una major degradació i potencial desaparició total ${ }^{5}$. Descobert i soterrat tan important edifici, passaren els anys $i$, al llarg de les dècades dels anys deu i vint, per tal de convertir "en frondosas plantaciones de frutales, aquel erial" es destruïren "aquellos paredones sagrados de la Basílica" (Ibarra Ruíz, 1926, iii), amb la qual cosa la destrucció i l'oblit s'apoderaven, semblava que definitivament, de l'edifici.

Així doncs, i llevat d'unes rases per comprovar la ubicació del mosaic l'any 1924 (Ramos, 1974, 77), les excavacions no es varen reprendre fins a l'any 1948 quan el nou propietari i investigador de l'Alcúdia, Alejandro Ramos, diu com "con motivo de celebrarse en Elche, en mayo de 1948, el IV Congreso de Arqueología del Sudeste Español, y conociendo la situación exacta del emplazamiento del mosaico (...) decidí descubrir dicho mosaico, con la doble finalidad de exponerlo a la vista de los congresistas y después proseguir las excavaciones a su alrededor, a fin de poder completar el estudio de tan importante monumento" (Ramos, 1955, 130).

Seguint la publicació referent a eixe any 1948 (Ramos, 1955, 130-133), aixi com una obra de caràcter més general on, molts anys després, Alejandro Ramos (1974, 103-109) amplià la breu informació consignada a la memòria d'excavacions, veiem com, un cop redescobert el mosaic, continuà cap a l'est, desenterrant de nou l'absis al seu nivell de cementació i trobant el cancell amb forma de cavall que analitzaria anys després com a visigot (Ramos, 1972). Més enllà ( $\mathrm{n} .1$ del seu croquis, Fig. 2), excavà un compartiment de 4 $\times 9 \mathrm{~m}$ amb paret de carreus al nord i a l'est, i va localitzar diverses teules al cantó nord-est i va destacar que, al costat est "cuyo piso es un empedrado recubierto de mortero de cal, perdido ya en la mayor parte de su superficie, encontré (...) varios pequeños bronces de los emperadores Constante I, Constantino I y Galieno (anys 260-361), y una moneda incompleta, en mal estado de conservación, pero, al parecer, de tipo bizantino" (Ramos, 1955 , 131). En aquesta habitació (Ramos, 1955,132 ) va identificar un nivell inferior en $12 \mathrm{~cm}$ a l'anterior, amb un bronze de Galienus (260268), un altre nivell $20 \mathrm{~cm}$ més baix amb ceràmica ibèrica, un sòl anterior empedrat amb grans pedres $i$ tovots $25 \mathrm{~cm}$ per sota $i$, finalment, materials ceràmics pintats -ibèrics?$i$ objectes de ferro.

Cap al nord (Ramos, 1974, 132), entre el mur de carreus $\mathbf{i}$ un altre que interpretà posterior, va trobar (Fig. 2, n.2) un "departamento (...) a modo de pequeño patio o vertedero" ple de ceràmica ordinària, grisenca i sigillata. Al nord d'aquest, i delimitat per un mur amb portal a l'oest, una estructura amb un sòl de terra maçonada, amb una lleugera capa d'arena fina i materials molt diversos, amb ceràmica ibèrica, sigillata i ceràmica grisa fumarada i roja mat amb formes corresponents a olles i bols - ¿potser el Grup 7 de Paul Reynolds (1993) o Forma / de Sònia Gutiérrez Lloret (1996), pròpies del segle VII?-. Per sota d'aquest nivell, a l'altura del mosaic i delimitat amb un terra de graves, trobà més fragments de sigillata i ceràmica grisa fumarada i roja mat, i una tessella del mosaic. En eixe mateix departament, va prosseguir l'excavació trobant un mur de carreus d'est a oest i restes d'un altre, baixant fins al que interpretà com el nivell ibèric.

D'altra banda, per tal de delimitar els murs de tancament del mosaic, va fer una calicata al nord (Fig. 2, n.3), amb material ceràmic d'època ibèrica, romana i "romana

\footnotetext{
5 Tal i com relata Pere Ibarra: 1907, Setembre, 7. Efeméride 592. "Ayer fue rellenado el hoyo en cuyo fondo está el pavimento de mosaico, de la que fue Basílica de lllici. Desde su descubrimiento, ha sido visitado el mosaico por infinidad de forasteros, que todos, cual más, cual menos, han querido conservar un recuerdo del hermoso dibujo. Ante tamaña profanación, y destrozo, el dueño, con el consejo de los que lamentamos el hecho, no podemos evitarlo, nos ha complacido. dando orden para que se cubra ese maravilloso monumento artístico, que, sabe Dios, cuando volverá a ver la luz del Sol. (...)" (AHME, 70-B-030.000).
} 


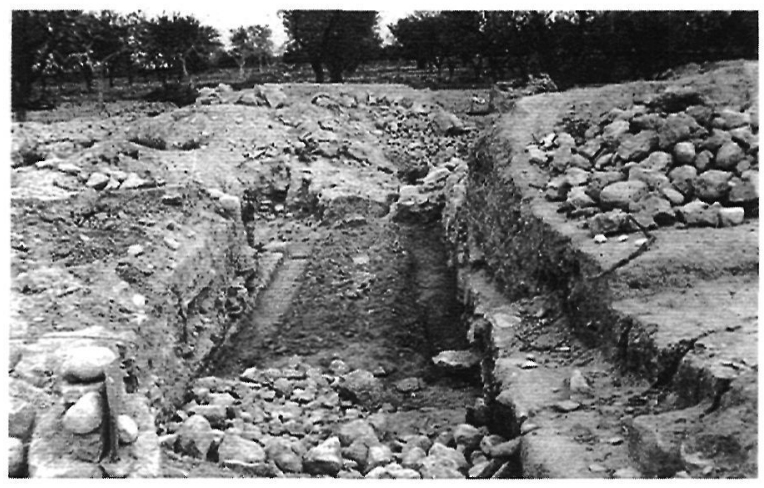

Figura 3: Carrer del costat sud de la basílica, excavat el 1949 (Ramos Fernández, 1975, 99).

avanzada", però sense esmentar el mur, "dando todo ello la sensación de estar alterados los niveles al hacer los cimientos del muro del mosaico y a la destrucción del mismo" (Ramos, 1955, 133). Uns anys després (Ramos, 1974, 104-105), diria com eixe mur nord de l'edifici, de $70 \mathrm{~cm}$ d'amplària i "sólo conservado en sus cimientos" es continuava més enllà del mosaic, cap a l'est, conformant la unitat arquitectònica que plasmà al seu croquis original com a límit sud dels espais 2 i 3 (Fig. 2). Al sud del mosaic (Fig. 2, n.4), al nivell superior, trobà restes d'estuc decorat i una paret formada per carreus, pedres, estuc i d'altres materials d'enderroc, així com restes d'un altre mur no precisat relacionat amb un soterrament (Ramos, 1955, 133); aspecte que serà tractat en parlar de la necròpolis. Igualment que pel que fa al mur nord, molts anys després (Ramos, 1974, 107108) ampliaria aquesta breu informació amb diverses i molt interessants dades sobre superposicions i tipus constructius.

En la memòria de l'any 1948 Alejandro Ramos no fa esment d'haver avançat cap a l'oest del mosaic, però posteriorment (Ramos, 1974) precisà que no va poder trobar aquell sial de pedra calcària de $135 \times 50 \mathrm{~cm}$ que descrivia Eugène Albertini al final del paviment, sinó només "un hueco que en su día debió estar ocupado por el referido barrón o peldaño del umbral, pero no interrumpiendo la pared, sino junto a ella por su lado externo" (Ramos, 1974, 104). Parla inclús d'una "pileta circular de piedra caliza de $36 \mathrm{~cm}$. de diámetro exterior" (Ramos, $1974,104)$ que suposa hauria trencat el mosaic, i que no havia sigut esmentada per cap dels dos primers excavadors ${ }^{6}$. No obstant això, l'opció que ací defensem és que ni Eugène Albertini ni Pere Ibarra varen donar massa importància a aquesta pileta, que pareix correspondre a la forma circular de la Fig. 11, per interpretar-la com una de tantes reparacions del mosaic -les mouvais dallage del croquis d'Eugène Albertini (Fig. 1)-, i que no trencaria, doncs, el mosaic, sinó que es tractaria d'una reparació reaprofitant una pileta de tendència plana.

El 1949 Alejandro Ramos va prosseguir les excavacions, ara a la zona sud de la basílica (Ramos, 1956, 104-105), cosa que li va permetre conèixer l'existència d'un carrer de traçat recte, direcció est-oest, afrontat amb el lateral sud de la basílica, de quatre metres d'amplària amb voreres de pedra i una pavimentació de grava i roca (Fig. 3). I constatà diferents estrats que abraçarien des del segle $\mathrm{VI}$ aC fins a un moment contemporani a la basílica $^{7}$ (Ramos Fernández, 1995b).

Després d'aquesta excavació desenvolupada l'any 1949 només es va produir una actuació puntual l'any $1954^{\circ}$. D'altra banda, amb l'ajut del Deutsches Archäologisches Institut de Madrid es va alçar el paviment de mosaic, muntant-lo en planxes de ciment de $7 \mathrm{~cm}$ de gruix i d'uns $3 \mathrm{~m}^{2}$ aproximadament, i se'n realitzà un dibuix per $\mathrm{C}$. Zamora l'octubre de 1965 (Ruíz Roig, 2001, 40), per tal de poder excavar sota la planta de l'edifici. A finals de la dècada dels vuitanta Rafael Ramos (1995b) excavà per sota de la planta basilical (Fig. 4), exhumant el que va considerar temple ibèric de l'Alcúdia abandonat cap a l'any 10 aC, que

\footnotetext{
- "Esta pileta no ha sido mencionada por los excavadores del año 1905. La pieza de referencia está sujeta al suelo con barro y hállase rodeada de pequeños fragmentos de tableros de mármol de varios tamaños y diferentes colores. En su interior encontré varias teselas blancas y negras, pertenecientes al mosaico. El borde de esta pileta dista de la pared, o mejor dicho, del borde del pavimento en su lado oeste, tan sólo $16 \mathrm{~cm}$. Al observar este descubrimiento tuvimos la sensación de que era una pieza que fue colocada después de hecho el mosaico y que, para su colocación hubo necesidad de romper una parte de dicho mosaico; y, que, después de colocada la pileta no siendo capaces de restaurar la parte de mosaico destruido, se suplió con los fragmentos de mármol y ladrillo que la rodean" (Ramos, 1974, 104).

${ }^{7}$ Probablement l'últim paviment, relacionat potser amb l'última fase d'ocupació de la basílica, siga un pis de graves de 25 $\mathrm{cm}$ de grossor "existiendo entre la grava fragmentos de terra sigillata y de lucernas", a una cota $70 \mathrm{~cm}$ per sobre del nivell del mosaic-que així haguera quedat molt per sota del nivell del carrer-(Ramos, 1974, 109).

8 "(...) a causa de las lluvias, (...) nos trasladamos al oeste del lugar, donde se hallaba el mosaico de la basílica, en donde encontramos unos fragmentos de cancel. También hice unas pequeñas catas al Oeste del lugar donde fue descubierto el mosaico de la supuesta sinagoga, encontrando adosado al muro un tubo en forma de ánfora para el desagüe, que vertía a la calle" (Ramos, 1962a, 93).
} 


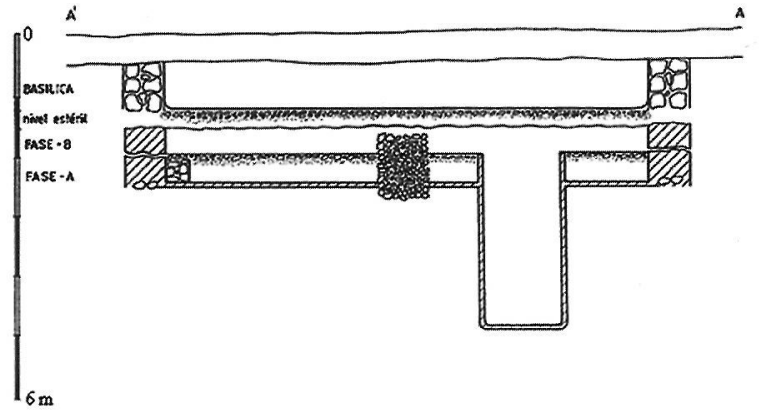

Figura 4: Estratigrafia de la basílica i del temple ibèric (Ramos Fernández, 1995b, 10).

fou reproduït a 15 metres al costat de la seua primitiva localització -com hui dia es veu-, recol-locant-hi posteriorment els murs de la basílica (Ramos Fernández, 1995b, 135).

"La excavación realizada informó de la secuencia estratigràfica siguiente, un estrato de $0,14 \mathrm{mts}$ de potencia, situado entre el nivel de preparación de suelo sobre el que descansaba la lechada de cal, a su vez soporte del pavimento de mosaico de la basílica, del estrato que lo cubría y el inicio de un nivel de escombros que corresponde a la composición del estrato inferior. Consiste en una sedimentación natural, arqueológicamente estéril, que expresa un abandono humano de la zona durante un amplio período cultural" (Ramos Fernández, 1995b, 9).

Després de molts anys de nova espera, $i$ amb motiu d'una restauració de l'edifici basilical duta a terme a principis de la dècada dels anys noranta (Ramos Fernández, 1995a, 1231), el mosaic ha tornat a ser collocat al sòl que originalment va pavimentar, una operació no exempta de problemes i que ha estat utilitzada per a datar la basílica, tal i com veurem, conformant-se la planta de l'edifici que actualment es pot contemplar (Fig. 5).

\section{ALGUNES CARACTERISTIQUES CONS- TRUCTIVES}

Un cop vistos els diferents processos d'excavació a què es va veure sotmesa la sinagoga-basílica d'llici, i seguint les descripcions donades pels seus excavadors, és hora ja de mostrar una visió general sobre les seues caracteristiques constructives i sobre les més significatives troballes allà efectuades. Fent, però, una mínima dedicació al mosaic les inscripcions del qual provocaren el naixement de la polèmica envers l'adscripció litúrgica- cultural de l'edifici, segons es considerara cristià o jueu.

Així doncs, seguint ara Pere Ibarra (1906), tenim que l'edifici es troba al sud de la lloma, $240 \mathrm{~m}$ al sud de les termes occidentals excavades el 1890, i $158 \mathrm{~m}$ a l'oest del punt on va aparèixer la Dama d'Elx. L'edifici, tal com es veia el 1905, presentava un mosaic amb forma de quadrilàter de $10,90 \times 7,75 \mathrm{~m}$, orientat est-oest, amb un petit hemicicle al centre del costat que mira cap a l'est, i un "portal de cantería" d'1,35 x 0,50 m al costat oest. El paviment de mosaic els hi va aparèixer tancat per parets al nord i oest, i a una profunditat d'1 $\mathrm{m}$ respecte del nivell superficial del terreny agrícola.

Pel que fa als murs de tancament del mosaic, molt malmesos, resulten difícils d'explicar per la pèrdua d'informació deguda a l'antiguitat de les investigacions i el fet de constatar-se gairebé només a nivell de cimentació -cosa que va fer-los passar desapercebuts als ulls dels primers excavadors-.

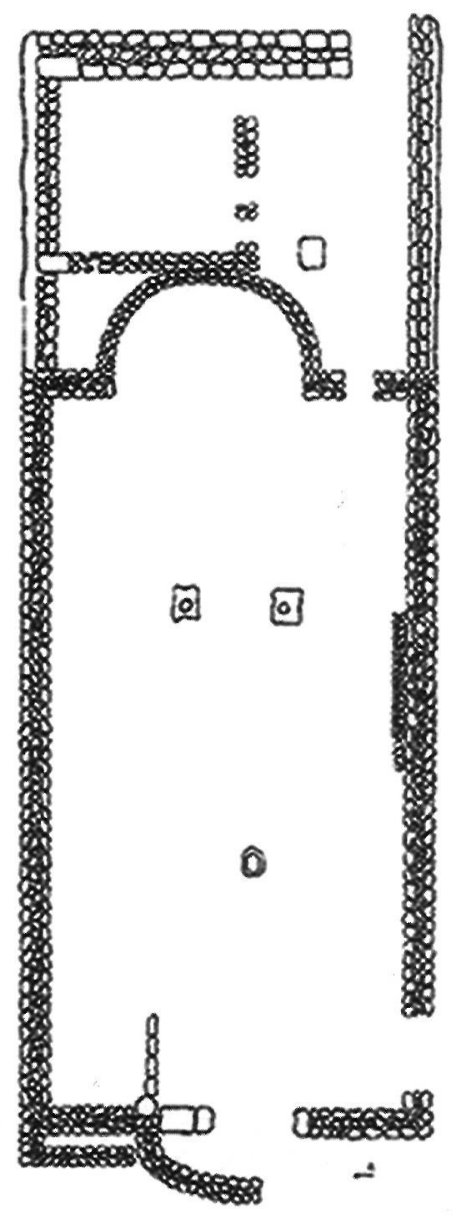

Figura 5: Planta de l'actual edifici (Ramos Molina, 1997). 
I només Alejandro Ramos (1974) va dir alguna cosa sobre els murs, a partir de les seues pròpies investigacions, tant pel que fa al tancament al nord ${ }^{9}$, com a l'oest ${ }^{10}$, al sud ${ }^{11}$ i a l'est ${ }^{12}$ del mosaic. Una anàlisi exhaustiva d'aquests murs la deixem, però, per un altre moment.

Pel que fa al paviment, probablement format després de construïdes les parets que el tancaven ${ }^{13}$, no cobria l'absis identificat a l'est, ni tampoc dues pedres quadrangulars, de $85 \mathrm{x}$ $70 \mathrm{~cm}$ aproximadament, encastades "casi al ras" del paviment, i amb dos petits forats respectivament, potser per aguantar un espigó. Situades una a 2,40 m del costat nord-del mosaic o del mur?-, i a 1,70 la pedra següent, ambdues en una línia recta nord-sud que es distanciava $4,10 \mathrm{~m}$ del costat est del paviment -el relacionat amb l'absis-, potser serviren a mena de transenna o barana, per tal de separar els fidels de la zona del santuari. Tampoc no tenien paviment els dos angles de l'est, ubicats als cantons dret $\mathrm{i}$ esquerre de l'absis. Pere Ibarra $(1906,122)$ identifica el de l'esquerra vist des de l'absis-com l'epístola, assenyalant una construcció en forma d'arc configurat amb una mena d'escalons, mentre que a la dreta no es conservava res. Uns altres escalons varen ser esmentats i dibuixats per Eugène Albertini $(1907,121)$, però sense forma semicircular sinó quadrangulars (Fig. 1), pareix que a sobre dels altres, cosa que possiblement ens estiga posant davant una evolució formal de la zona potser amb una mateixa funcionalitat ${ }^{14}$.

Pel que fa a l'absis ja esmentat, les diferències entre ambdós autors són grans però, en bona part, complementàries. Així doncs, Pere Ibarra el veu com un hemicicle de $3,20 \mathrm{~m}$ de profunditat des del final del mosaic, mentre que Eugène Albertini (1906a, 619) parla d'un radi de $2,10 \mathrm{~m}$ de profunditat on "est comprise l'épaisseur du mur", a més que per al primer el costat sud de l'absis toca al paviment i per al francès queda a dos metres del mosaic. L'aparent contradicció, mantinguda com una estranya discrepància entre els dos autors des de Helmut Schlunk (1948), qui realitzà la més científica i completa anàlisi sobre les publicacions dels dos excavadors ${ }^{15}$, no és tal si

\footnotetext{
s "Este muro (que, junto al mosaico, sólo se conserva del nivel del pavimento hacia abajo, siendo su ancho de 0 ' $70 \mathrm{~m}$.) junto al departamento $C$. conserva una altura de unos $0^{\prime} 45$ $\mathrm{m}$. sobre el piso, estando formada esta pared por sillarejos a partir del nivel del pavimento, que en este departamento es de mortero de cal. La pared de referencia, bien construída
}

en su cara externa por un paramento convexo de mortero de cal, tal vez para proteger el muro de la humedad en caso de lluvia. Dicho departamento convexo se prolonga hacia el Oeste y llega muy cerca del mosaico, y ello nos hace suponer que, tratándose de unos mismos cimientos de pared desde el mosaico hasta el rincón Oeste de la dependencia $\mathrm{C}$, el muro de sillarejos debería ser igual en todo el tramo en que subsiste el bordón o paramento protector que tiene el muro, y probablemente también en el muro del mosaico" (Ramos, 1974, 104-105).

10 "Del muro Oeste, pocos restos quedan, pero los suficientes para conocer que se trata de una pared construida de similar manera que la pared del Norte" (Ramos, 1974, 104)

11 "Del muro del Sur, de la misma estructura y características que el del Norte, sólo se conservan unos diez centímetros en la parte visible. Sobre los restos de este muro se construyó otro, cuya longitud rebasa las dimensiones del mosaico tanto hacia el Este como hacia el Oeste, siendo de notar que hacia la parte central del mismo una pared monta sobre la otra dejando por cubrir unos veinte centímetros de la inferior, pero luego, la pared superior se desvía un poco hacia el Norte, en diagonal, cubriěndola por completo. Sobre esta segunda pared se eleva otra o parte de ella formando un escalón. Estas últimas construcciones murallas prolongan hacia el Oeste, y al parecer corresponden a otra construcción posterior al pavimento mosaico, construcción que luego cierra en el Oeste. La única diferencia que observo entre estas paredes es que en la inferior, o sea, la que a mi juicio corresponde al mosaico, se ha utilizado más piedra que en las superiores en las que hay más predominio del barro" (Ramos, 1974, 105 106).

12 "(...) se conserva en los extremos Norte y Sur del mosaico, en una longitud aproximada de metro y medio al norte y medio metro al sur, o sea, que poco más o menos llegan dichos restos de pared hasta frente al arranque del arco de circunferencia que constituye el supuesto ábside. Dichos restos de pared son de similar estructura que el muro Norte, y forman una pieza con los muros laterales, por lo que debieron de ser construidos simultáneamente" (Ramos, 1974 , 105-106).

13 Aixi pareix desprendre's d'una observació d'Alejandro Ramos que, malauradament, ja no es pot comprovar: "Un detalle digno de hacerse notar es que, en los muros Norte, Este y sur, que delimitan el mosaico, se conservan en su cara interna, restos del estuco o enlucido de la pared, que aparecen entre los muros y el mosaico, de lo que deduzco que este fue compuesto después de hechas y enlucidas las paredes. Los estucos son de color negro en la pared del Este y blancos en las demás" (Ramos, 1974, 105). És interessant veure que policromadament es marque una diferència amb la paret que donà cabuda a l'absis, potser pensada des d'un primer moment com a diferenciada de la resta. Però l'estat actual de la investigació obliga a la prudència.

14 Recentment (Márquez i Poveda, 2000, 194-195) s'ha apuntat la possibilitat que aquests escalons, juntament amb un immediat motiu del mosaic, es relacionaren amb un baptisteri que es trobaria adjacent al costat est de l'edifici, en la zona sud. Si es confirmara la nostra intuïció de dues fases constructives amb un mateix objectiu que precisa d'escalons, potser futures investigacions puguen reforçar la idea del baptisteri, o d'alguna altra funció diacrònica, a aquesta zona.

15 Conclusions que han aprofitat la resta d'investigadors ( Vid. Ramos, 1955; 1970; 1972; 1974; De Palol, 1967; Llobregat, 1978; 1985; Ramos Fernández, 1975; Ramos Molina, 1997). 
tenim en compte allò que volia dir cadascun d'ells.

"A l'est de la mosaïque, un mur épais de 0 '58 dessine une abside semi-circulaire, dont le rayon est de 1'50. (en nota: J'ai employé des termes inexacts dans ma note des Comptes rendus de l'Académie (1905, p.619): il ne fallait pas parler d'arc de cercle, mais de demicercle; et dans la mesure de 2'10 que j'indique comme la hauteur de l'arc, est comprise l'épaisseur du mur). Un intervalle d'un mètre sépare du pavement en mosaĩque l'extrémité nord de l'abside; la partie sud de l'abside est moins entièrement conservée et s'arrête à deux mètres de la Mosaïque. L'axe de l'abside est sur le prolongement de l'axe du pavement rectangulaire, et nous avons vu que la mosaĩque a 7'55 de largeur, le mur de l'abside 0'58 d'épaisseur: en abaissant deux perpendiculaires des extrémités de l'abside -supposée aussi complète au sud qu'au nord-sur le pavement, il resterait donc en dehors de l'abside une largeur d'environ 1'70 de chaque côté" (Albertini, 1907, 121).

"(...) no conserva pavimento el hemiciclo o ábside, que no tenía piso alguno, y mandé excavarlo en su interior por si se encontraba algo de interés. Encontróse, en efecto, una basa ática en piedra de cantería, y dos sillares sueltos, elementos suficientes para determinar la existencia en aquel punto del objeto de mis pesquisas, del altar. (...) El ábside consiste ni más ni menos que en un semicírculo de 3'20 $\mathrm{m}$. de profundidad desde el borde del mosaico, no apoyando sus extremos en el pavimento nada más que por el lado Sur (...)" (Ibarra Ruíz, 1906, 121 i 126).

La idea que defensarem a continuació és que les diferències entre ambdós autors, "Ios cuales publican separadamente sus Memorias, que en muchos extremos dejan de coincidir, en especial en la interpretación del ábside tardío" (De Palol, 1967, 64), no es donen per una doble interpretació de l'absis, sinó que corresponen a dos moments diferents de l'excavació, atès que Eugène Albertini i Pere Ibarra probablement no varen excavar tan junts com s'ha pogut suposar. És així que l'autèntic excavador de la basílica fou Eugène Albertini, malgrat que alguns dies rebera la visita de Pere Ibarra, especialment després d'haver excavat tota la superfície del paviment, per l'interès que, sens dubte, va causar-li el mosaic.

I així s'explica que Eugène Albertini parle d'allò que trobà per sobre del mosaic -els tres fragments de capitells corintis i de volutes, el timbal de columna i els fragments dels finestrals àrabs-, que precise l'absis com a separat $1 \mathrm{~m}$ del paviment a la part nord i $2 \mathrm{~m}$ al sud, amb $1,50 \mathrm{~m}$ d'arc intern i $2,10 \mathrm{~m}$ d'arc extern, i que indique que la terra entre el mosaic i l'absis havia estat remoguda "depuis l'époque antique". I també s'entén que precise l'aparició de l'absis $10 \mathrm{~cm}$ més baix que el mosaic, i que registre eixe mur d'aparença irregular que cobria el mosaic sobrepassant-lo, flanquejat al final per uns escalons al sud i un terra formigonat al nord -és a dir, entre l'absis i el mosaic- també 10 $\mathrm{cm}$ per sota del mosaic. I per contra, però no sorprenentment, res de tot això fou transmès per Pere lbarra, simplement perquè com a fases de l'excavació anteriors al total descobriment del mosaic, ell no hi estava present.

Davant tota aquesta valuosa informació, cal fer notar que l'informe d'Eugène Albertini no indica en cap moment l'excavació de l'absis que transmet Pere Ibarra, probablement perquè aquesta es va produir quan el primer ja havia abandonat el jaciment, cosa que podria confirmar-nos que Pere Ibarra indique "mandé excavario" en singular, i que explica també que Eugène Albertini no tracte la base de columna àtica ni dels dos carreus que el seu col-lega va interpretar com a parts de l'altar.

Finalment, açò ens explicaria per què, malgrat tot, ambdós veuen l'absis construït mitjançant un mur de 58 o $60 \mathrm{~cm}$ aixecat amb materials d'enderroc i sense cap tipus d'arrebossat, atès que n'és un resultat d'excavació que, conservat in situ per les respectives excavacions, tots dos van poder examinar. I ens porta al punt que historiogràficament s'ha plantejat com una divergència entre els excavadors, és a dir, si l'absis arribava o no fins al paviment de mosaic

En el moment actual de la investigació, i malgrat la falta de detall a les fotografies antigues (Fig. 6), la diferència d'opinió podria ser deguda a què, al llarg de l'excavació interior de l'absis, Pere Ibarra buscà les prolongacions que pensava que anirien del mur cap al paviment, trobant un desenvolupament del mur cap a l'oest a més profunditat de la que va arribar Eugène Albertini ${ }^{16}$, i per això el mur enderrocat en forma desigual, i no descobert en la seua totalitat, hauria distorsionat les mides

\footnotetext{
16 Helmut Schlunk $(1948,336)$ ja va suposar-ho quan diu: "En el Este, sin embargo, si nos atenemos a las indicaciones de lbarra, no existió cimentación alguna, aunque sí un resto de un ábside semicircular de un metro de altura, que llegó, aunque en menor altura, en el lado Sur hasta el término del rectángulo anterior".
} 



Figura 6: Fotografies de detall de l'absis, dels treballs de Pere Ibarra (Ibarra Ruíz, 1906).
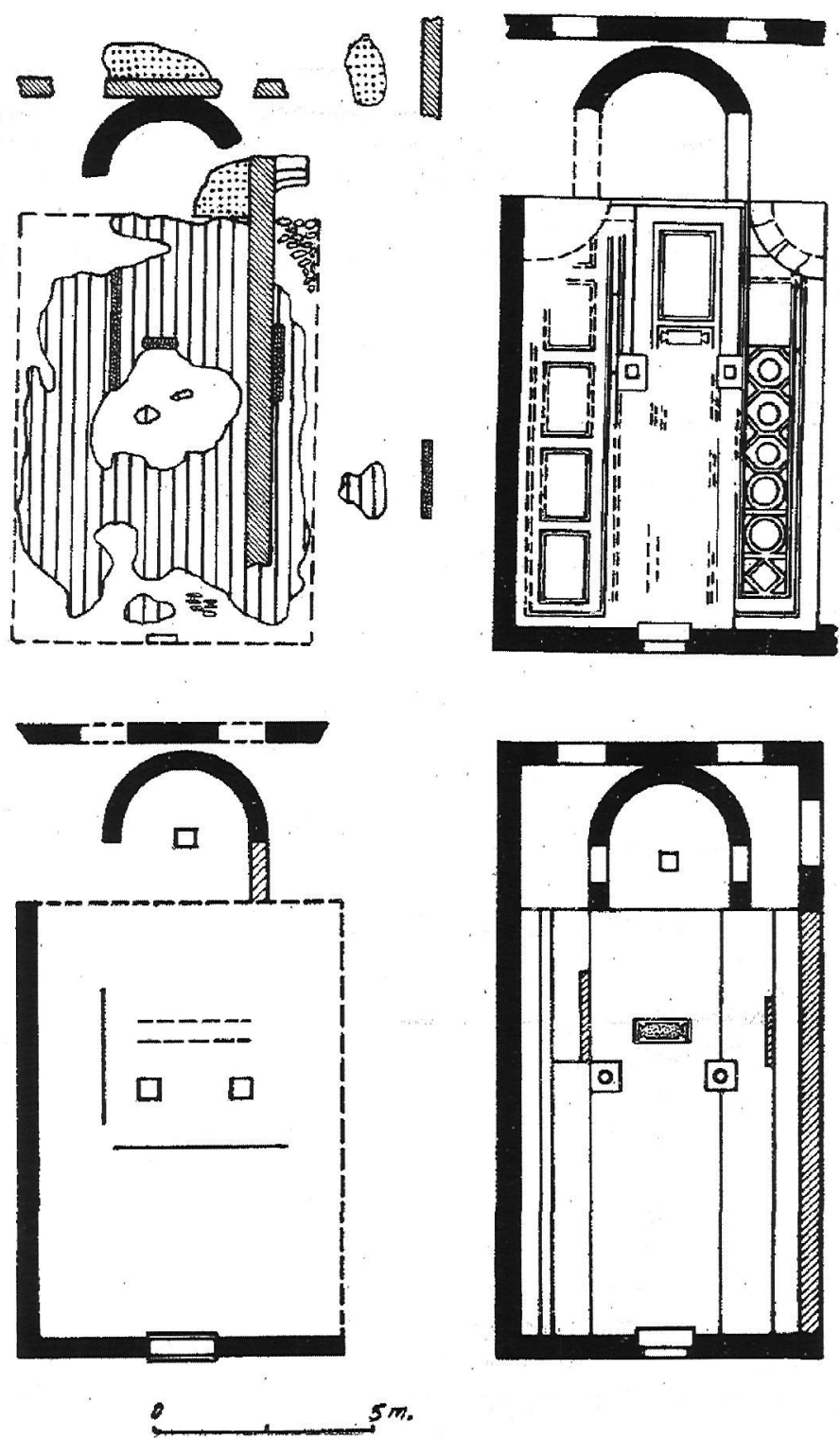

Figura 7: Versions de la planta de la basílica d'llici (De Palol, 1967, 65). a) E.Albertini; b) P.Ibarra; c) J.Puig i Cadafalch; d) J.Lafuente. 
de l'arqueòleg francès, que va agafar-les respecte d'un mur el recorregut del qual no acabà de determinar.

Aixi explicaríem la divergència observable entre la planta d'Eugène Albertini i la de Pere Ibarra i els que en ell s'han basat, especialment pel que fa a l'absis que hem tractat d'explicar, tal com ens mostra la comparació feta per Pere de Palol $(1967,65)$ (Fig. 7). Veiem, doncs, com Pere Ibarra -amb el seu característic estil de dibuix ${ }^{17}$ - mostra com sí que va veure el prolongament de l'absis; una interpretació que recull Josep Puig i Cadafalch (et alii 1909) i més endavant José Lafuente (1948), i que pareix observar-se en una planta amb diverses cotes apareguda posteriorment (Schlunk y Hauschild, 1978, 9).

Pel que fa al muret que "tancava" l'absis per darrere, citat i dibuixat pels dos excavadors, Eugène Albertini $(1907,127)$ l'interpreta com pertanyent a una fase posterior i contemporani al mur que travessava el mosaic d'oest a est ${ }^{18}$, Josep Puig i Cadafach el considera el tancament d'una originària forma rectangular "deixant als dos costats dos sacristies ab comunicació ab ell" (Puig i Cadafalch et alii, $1909,293)$, i Manuel Sotomayor $(1979,145)$ diu que "el muro que en los planos publicados se ve tras el ábside es un muro estucado, perteneciente a construcciones anteriores, a las que se adosó la basílica". Tres opcions -anterior, contemporani o bé posterior-que no han sigut desenvolupades amb posterioritat i que han deixat encara obert el tema.

D'altra banda, si els primers excavadors discrepaven sobre si l'absis arribava o no al paviment de mosaic, i molt promptament es va suposar que estaria emmarcat dins un rectangle (Puig i Cadafalch et alii, 1909, 293 i 297), amb posterioritat (Schlunk, 1948; 337-338 i 344-345) es va suggerir que correspongués a un moment lleugerament posterior al paviment, potser al S.V ${ }^{19}$, o inclús al S.VI (Ramos, 1974, 100). Aquesta argumentació va acceptar-la i difondrela Pere de Palol el $1967^{20}$, i des de llavors ha sigut mantinguda -i copiada pel que fa a l'obra de Helmut Schlunk- pels últims investigadors del jaciment (Ramos, 1974, 97-100; Ramos Fernández, 1975; 243; 1984, 16), "si bien esta datación se apoya sobre todo en una valoración contextual del edificio y su evolución en el marco de la arquitectura paleocristiana y no en datos arqueológicos concretos" (Márquez i Poveda, 2000b, 193) ${ }^{21}$. Una altra opció ha sigut encunyada per Enric Llobregat $(1991,171)$, suposant l'absis del S.VII, contemporani dels cancells i "quizá englobado en una cabecera cuadrangular", i finalment s'ha suposat corresponent al moment fundacional (Ramos Molina, 1997, 46).

En l'estat actual de la investigació també resulta problemàtica la relació amb el fragment de paviment "en ciment grossier, à un niveau légèrement supérieur au niveau de la mosaïque" de què parlà Eugène Albertini (1907. 121), i la relació amb les estructures descobertes per Alejandro Ramos el 1948 (Ramos, 1955).

Altrament, al llarg de les diferents excavacions efectuades en aquest edifici religiós, s'hi varen documentar diverses significatives troballes, com ara (Fig. 8) el 1905, amb peces ceràmiques completes o quasi teules o vasos, gerres, etc.-, objectes metàl-lics i fragments d'escultures, com dels finestrals a la part esquerra, baix. D'aquestes troballes que, majorment en pedra, moltes han pervingut fins a l'actualitat, farem només breu esment.

Així doncs, provinents de les primeres actuacions del 1905, Alejandro Ramos (1974, 107-108) transcriu alguns documents inèdits de Pere Ibarra referits a diferents troballes efectuades al llarg de l'excavació de la

\footnotetext{
17 "(..) los muros claramente reconocibles han sido rellenados con negro mientras que los que Ibarra creyó poder reconocer, fueron indicados por lineas continuas laterales, y los supuestos por líneas interrumpidas", (Schlunk, 1948, 359). Cosa que es pot comprovar al mapa de la lloma de L'Alcúdia que va confeccionar al llarg de 1890, actualment conservat a un despatx del Museu Monogràfic de L'Alcuidia.

18 "(les Arabes) ce sont eux, selon toute vraisemblance, qui ont construit en outre le mur $a b$, et le mur tangent par derrière à l'abside, avec le pavement grossier qui l'accompagne" (Albertini, 1907, 127).

19 " $\mathrm{Si}$, por un lado, es ciertamente extraño que el ábside, al parecer, no esté claramente ligado con el rectángulo (...), que no tenga piso de mosaico, que arranque de un nivel más bajo, sorprendería, sin embargo, que fuese de fecha anterior, puesto que se conservaba en el momento de la excavación, con una altura que oscilaba entre $80 \mathrm{cms}$. $Y$ un metro. Es más que probable que si fuese una construcción anterior se hubiese destruido antes. Más verosimil parece en nuestra opinión, que se trate de una construcción, y con esto está de acuerdo el carácter del aparejo de relleno, como anotan Albertini e lbarra, y pudiera datar del momento en que el suelo de mosaico, que el emplazamiento del ábside no toma en cuenta, ya no tenía su antiguo destino" (Schlunk, 1948, 344).

20 "Es decir, una aula rectangular, sinagoga, perteneciente al siglo IV, a la que se añadiría en un momento posterior un ábside en su posición litúrgica cristiana normal, al Este, cerrado por un muro exterior que permitia dos sacristías laterales" (De Palol, 1967, 66).

21 Com a paral jels propers, al jaciment del Monastil es defensa la incorporació d'un absis de ferradura al S.VI a l'edifici religiós constatat (Márquez i Poveda, 2000a, 179).
} 


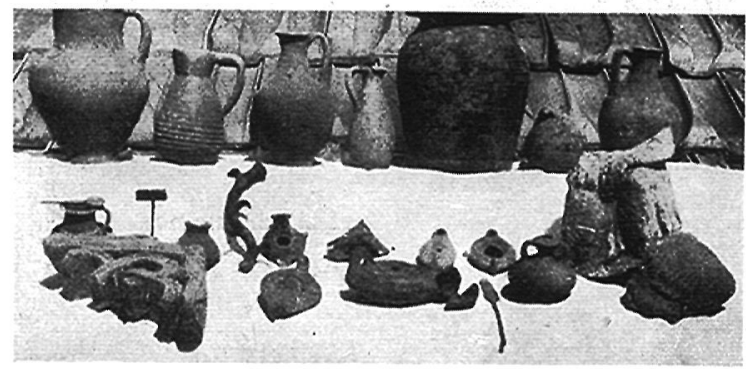

Figura 8: Fotografia de Pere lbarra de part de les troballes efectuades el 1905 a la basílica (Ramos, 1952).

basílica ${ }^{22}$; que parlen de dues columnetes -una d'elles grega-, tres dies abans de mostrar sencer el paviment de mosaic l'11 d'agost:

"El mismo Ibarra en su Efemérides 491 del 8 de Agosto de 1905, hace relación de los objetos encontrados en la campaña de dicho año, según la materia, piedra, bronce, cerámica, etc., y en uno de sus párrafos, dice: "Como dato curioso algunos fragmentos decorativos bizantino-orientales; con toda la apariencia del estilo árabe". Aclara un poco este extremo las notas consignadas en su catálogo en el que dice:

"No 1.- soporte o columnita estriada en espiral, taladrada en toda su longitud: tiene tres hoyitos en el anillo superior que hacen suponer si servirían para empotrar alguna pieza de remate: tal vez un surtidor. Alta: 0'34.- Diam. en la base, 0'15.- Diam. del anillo superior, 0'10.- piedra dura. Fue hallado cuando se escombró la Basílica por Albertini en 1905.Serà el pie del Labrum o pila del agua bendita?".

"No 451.- Parte superior de una pequeña columna o soporte, griego, en arenisca, que saqué del fondo del ábside de la Basílica de Illici, en 1905; 0'33 diámetro fuste: altura trozo, 0'45: ábaco de 0'44, con hoquedad central y una ranura circular de 0'36 de diámetro".

D'aquestes primeres troballes destacaríem com en el procés del descobriment del mosaic policrom van trobar-hi tota una sèrie de fragments de pedra calcària tallada a bisell (Albertini, 1907; Ibarra, 1926) que, posteriorment, conformaren un bon grapat quan Alejandro Ramos $(1955 ; 1962)$ va prosseguir les excavacions a la zona, l'any 1948 , trobant-ne més. Aquests fragments de pedra han sigut, tradicionalment, interpretats com cancells visigots, o d'època visigoda, des de la publicació de diversos treballs ja clàssics; un d'especific (Ramos, 1972), un altre sobre la basílica (Schlunk, 1948), i dos més sobre el cristianisme en general aplicat al jaciment de l'Alcúdia (Ramos, 1974; Llobregat, 1985, 440-441).
Eugène Albertini $(1907,126)$, en qualsevol cas, va ser el primer excavador a buidar "la couche de terre, épaisse d'un mètre, qui séparait du sol la mosaïque" (Albertini, 1907, 126) i en trobar una sèrie d'elements arquitectònics, dels quals va destacar aquells fragments de pedra calcària que interpretà com a restes de finestres d'època i factura musulmanes:

"Mais les fragments les plus nombreux étaient de petits débris à surfaces généralement plates, à contours découpés, et décorés de lignes en creux. II fut facile d'en raccorder plusieurs entre eux, et d'obtenir ainsi un reste de grillage en pierre, certainement arabe, ainsi qu'une colonnette du même style, qui a servi sans doute de montant à une petite fenêtre (en nota: Hauteur de ce dernier morceaux: 0'35 m)".

El 1947 Helmut Schlunk $(1948,345)$ va postular d'aquestes peces "(...) que Albertini creyó pertenecientes a ventanas árabes, (...) que seguramente son anteriores, y formaban, al parecer, cancelas posiblemente del S.VII, (...) datos todos que confirman que (la basílica) sufrió varias transformaciones, subsistiendo pro(ba)blemente hasta la época árabe". Molt interessat pels cancells, el prolífic investigador alemany va reservar-los per a un estudi posterior, de l'existència del qual no n'hem trobat constància ${ }^{23}$.

A l'excavació de la basílica -i compartiments adjacents- practicada l'estiu del 1948, Alejandro Ramos trobà "entre los escombros un fragmento, posiblemente de cancel, en figura de cabeza de caballo, al parecer de estilo visigodo, de idéntica factura y labrado en la misma clase de piedra que los numerosos fragmentos encontrados en 1905 (...)" (Ramos, 1955, 130). I l'any 1954, "a causa de las lluvias, que inundaron la zona de las excavaciones" els treballs es traslladaren a

\footnotetext{
${ }^{22}$ Concretament transcriu notes de Pere Ibarra tant de les Efemérides illicitanas com del Catálogo de mis antigüedades, treballs inèdits actualment sense localitzar (Castaño, 2002, 345 ), als quals Alejandro Ramos va tindre accés probablement al llarg de la seua llarga etapa com a arxiver d'Elx, del 1939 a 1974. Vid. Alejandro Ramos (1952; 1974, 78-85), per a la transcripció de part d'aquestes Efemérides inèdites, i actualment perdudes, de Pere lbarra, on va transmetre el procés d'excavació i algunes de les més importants incidències de la campanya de la basílica.

${ }^{23}$ Segons la nota 72 precisava: "El estudio de estos canceles espero poder hacerlo en otra ocasión, y en conjunto con varios restos semejantes de otros monumentos" (Schlunk, 1948 371 ), però dels que ja pràcticament no en parla (Schlunk, 1952; Schlunk i Hauschild, 1978; Schlunk, 1982).
} 




Figura 9: Hipòtesi de restitució ideal de l'anomenat cancell de la basílica d'llici d'Alejandro Ramos (1974).

l'oest del mosaic, zona "en donde encontramos unos fragmentos de cancel” (Ramos, 1962, 93).

Amb tots els fragments es completà un conjunt ja important que va permetre a Alejandro Ramos publicar anys després, el 1972, "un cancel visigodo en la Alcudia de Elche" i, de seguida (Ramos, 1974), proposarne una reconstrucció amb tots els fragments trobats fins al moment (Fig. 9), buscant alhora diversos paral.lels dels segles VI-VII -com ara la basílica d'Algezares en Múrcia del S.VI, diverses troballes a Mérida del S.VII, i un finestral de San Juan de Baños del S.VII-, que justificarien aquella datació suposada per Helmut Schlunk $(1948,345)$ i que finalment li servirien per a datar tant els cancells com el moment d'esplendor de la basílica d'llici al S.VII (Ramos, 1972, 170); un argument reforçat perquè aquell seria el moment en què es constataven les signatures de bisbes de la ciutat en diversos concilis visigots.

Aquesta datació va rebre, més tard, suport (Llobregat, 1985, 440-441), però també fou matisada -finals del S.VI i tot el S.VII (Schlunk i Hauschild, 1978, 167)-, associantla a unes reformes efectuades en la basílica com a conseqüència de la presència visigoda en la ciutat (Márquez i Poveda, 2000b, 195). Paral-lelament (Ramos, 1972, 168-169; Schlunk, $1982,62)$ es va suposar que els cancells visigots s'ubicarien en dues pedres quadrades que aparegueren dins la basílica, emplaçades al terra i no cobertes pel paviment de mosaic, com a separació formal entre els fidels i la zona sacra de l'altar, segons l'antiga idea dels espigons de Pere Ibarra $(1906,121-122)$ i la seua descripció.

I aquesta és la interpretació que ha triomfat en la historiografia moderna del jaciment. Uns primers fragments trobats el 1905 , i a penes tractats per un dels excavadors, Eugène Albertini ${ }^{24}$, quasi quaranta anys després Helmut Schlunk va considerar-los possiblement cancells visigots del segle VII. Encoratjat per aquesta teoria, Alejandro Ramos en trobà més els anys 1948 i 1954 i va reforçar tant la funció com la datació. Els cancells visigots del S.VII, foren així reconeguts per Rafael Ramos el 1975, pel mateix Helmut Schlunk el 1978 i per Enric Llobregat el 1985, i aquesta interpretació s'ha mantingut posteriorment, vinculats als espigons de què parlara Pere Ibarra. Modernament només s'ha aportat una nova dada, de tipus estratigràfic, a un article de Jaime Molina i d'Antonio Poveda del 1995 sobre els nivells tardans d'abandonament del suposat forum d'llici, ja que relacionen un edifici romà reestructurat com a església al S.VII -amb reformes urbanistiques associades a l'edifici datades per ceràmica inequívoca del S.VII-, amb l'aparició dels cancells a la basílica puix "los fragmentos de cancel de la basilica y el Templo I son idénticos en técnica y en morfología, por lo que hemos de asignarles la misma datación (siglo VII)" (Molina i Poveda, 1995,152 , nota 6 ).

No obstant això, si bé la datació al S.VII de seguida va imposar-se -i pareix la més correcta, amb les precisions efectuades per Helmut Schlunk i Theodor Hauschild-, la primera interpretació com a finestrals, mantinguda només per Eugène Albertini, va caure en l'oblit, malgrat que no hi havia -no n'hi ha encara- una certesa suficient per a acceptar com a únicament vàlida la posterior idea dels cancells, que últimament defensen Alejandro Ramos Molina (1997) o Juan Carlos Márquez i Antonio Poveda (2000a i b).

D'altra banda, l'any 1954 Alejandro Ramos $(1962,93)$ va trobar-hi la base d'una columna octogonal que -hui desaparegudamodernament (Márquez i Poveda, 2000a,180) s'ha relacionat amb una altra columna apareguda en El Monastil (Elda, Alacant) que, també octogonal, fou transformada en heptagonal bisellant-hi un vèrtex, i que es data a finals del S.VI (Poveda, 1988, 133, Márquez i Poveda, 2000a, 180-182), posant-la a més en relació amb edificis religiosos d'època i influència bizantina. Extrapolant aquestes dades, podríem trobar-nos davant un testimoni de l'existència a llici a finals del S.VI, és a dir,

\footnotetext{
24 Tot i que Pere lbarra va trobar alguns fragments de cancel/s, i en l'article de 1906 explicava com "de otros varios fragmentos arqueológicos cristianos hallados ahora podríamos dar cuenta si no temiera extender demasiado este estudio" (Ibarra, 1906, 131), dissortadament no disposem de les seues Efemérides perdudes, on sabem per la transcripció parcial d'Alejandro Ramos (1974) que sí que en parlava, i en cap altra obra publicada no tractà mai el tema.
} 
sota el domini i la influència bizantina, d'un edifici religiós amb columnes de basa poligonals, tot i que perduda la peça i a l'estat actual de la investigació no es pot anar més enllà de l'especulació.

També recentment -abans es pensava que era del S.V (Llobregat, 1985, 438)- s'ha suposat corresponent a l'època de dominació bizantina una "mesa polilobulada de tradición oriental" de final del S.VI i amb paral-lels a la Mediterrània oriental (Márquez, 2000, 519-520) que, amb forma circular o de ferradura, sobrepassaria el metre de diàmetre, i que, interpretada com a taula d'altar ${ }^{25}$, tradicionalment s'ha suposat relacionada amb la basílica ${ }^{26}$ malgrat la falta de dades (Márquez, 2000,520 ), i que s'ha relacionat amb una altra basa de columna trobada a l'interior de l'absis excavat per el Pere Ibarra $(1906,121)$-que li faria de peu-, defensant-se erròniament que estaria in situ (Márquez i Poveda, 2000a, 180) ${ }^{27}$.
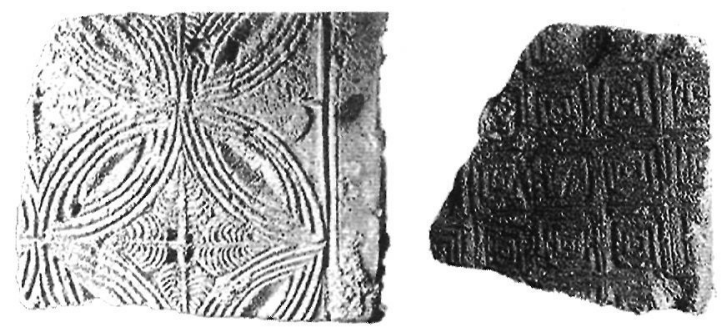

Figura 10: Lloses de pedra calcària probablement procedents de la basílica (Ramos, 1974).

I finalment, Alejandro Ramos $(1972,171)$ esmenta dues lloses incompletes de pedra calcària, tallades amb bisell i probablement procedents de la basílica (Fig. 10), decorada una amb cercles secants mentre que l'altra presentava una decoració amb quadrats inserits uns dins els altres, que resultarien "muestras del arte visigodo hallados en La Alcudia de Elche", i paregudes a "un trozo de friso de Mérida y unos canceles de Segóbriga" (Ramos, 1972,171 ). Pel que fa a la peça de l'esquerra, pareix factible assignar-li la funció de placa de cancell de factura visigoda, atesa la presència d'argamassa al cantell inferior dret i per la semblança formal amb un paral-lel del S.VII de format més senzill, registrat in situ, i perfectament contextualitzat (Sarabia, 2003, 167, fig.17) a la basilica visigoda del Tolmo de Minateda (vid. Abad, Gutiérrez Lloret i Gamo, 2000).

\section{EL MOSAIC POLICROM I LES INSCRIP. CIONS}

D'altra banda, i tenint en compte que va ser l'aspecte que més va cridar l'atenció dels mateixos excavadors i que ha comportat un dens tractament a la historiografia, ara és el moment més adient per a recordar les característiques tècniques i artístiques del paviment de mosaic de la basílica. Però hem de reconèixer-com a molts d'altres aspectesuna incapacitat manifesta per igualar o aproximar-nos a treballs anteriors -ja clàssicsd'autors consagrats, i per això emplacem als interessats en aquest punt a -especialmentPere Ibarra (1906), Helmut Schlunk (1948) i Pere de Palol (1967) o, pel que fa als aspectes purament artístics, Enric Ruíz Roig (2001).

Així doncs, únicament direm que es tracta d'un opus tessellatum atesa la concentració de 48 tessellae per $\mathrm{dm}^{2}$, deixant visible cadascuna d'elles una cara quadrada de $14 \mathrm{~mm}$ d'ample (Ruiz Roig, 2001, 40). Amb una policromia de

25 Tot i que el caràcter cristià d'aquesta peça, com a taula d'altar, que defensa Juan Carlos Márquez no pot assegurarse, segons es desprèn de la pròpia comunicació així com del posterior col-loqui (Márquez, 2000, 527).

${ }^{26}$ Igualment passa amb una peça esmentada per Pere de Palol $(1967,247)$, parlant de plaques reutilitzades i trobades en basíliques: "Una pieza interesante, procedente de Elche (Alicante) y hoy en el MAN de Madrid, sustituye el rombo central por una crátera agallonada, manteniendo las peltas", D'aquesta placa (de marbre?), probablement trobada per Aurelià Ibarra atesa la seua ubicació actual, desconeixem el $\| l o c$ al qual hi va aparèixer, però com que Pere de Palol va utilitzar-la per a il.lustrar una explicació de les reutilitzacions constatades en edificis basilicals, ací l'esmentem perquè resulta possible -només presentem aquesta gratuïta possibilitat-que puga relacionar-se amb la basílica d'llici, i tractar-se doncs d'un material romà aprofitat a època tardana, com segurament tant va haver-ne al jaciment de l'Alcúdia.

27 Pere lbarra $(1906,121)$ diu: "mandé excavarlo en su interior por si se encontraba algo de interés. Encontróse, en efecto, una basa ática en piedra de canteria, y dos sillares sueltos, elementos suficientes para determinar la existencia en aquel punto del objeto de mis pesquisas, del altar", Posteriorment, i citat per Alejandro Ramos (1974, 107-108), diu: "No 451.Parte superior de una pequeña columna o soporte, griego, en arenisca, que saqué del fondo del ábside de la Basilica de Illici, en 1905; 0'33 diámetro fuste: altura trozo, 0'45: ábaco de 0'44, con hoquedad central y una ranura circular de 0'36 de diámetro" (La cursiva és meua). De ser aquesta la columna a què fan referència Juan Carlos Márquez Villora i Antonio Poveda Navarro, no té gaire sentit suposar-la in situ, si és que es trobava al "fondo del ábside" que Pere Ibarra va excavar, del reblit del qual Eugène Albertini $(1907,126)$ indica expressament -"de toute évidence"- que la terra ubicada entre el mosaic i l'absis havia estat remoguda "depuis l'époque antique", ja que va trobar-se una important acumulació de pedres bastes que havien degut ser llançades allà a propòsit. 


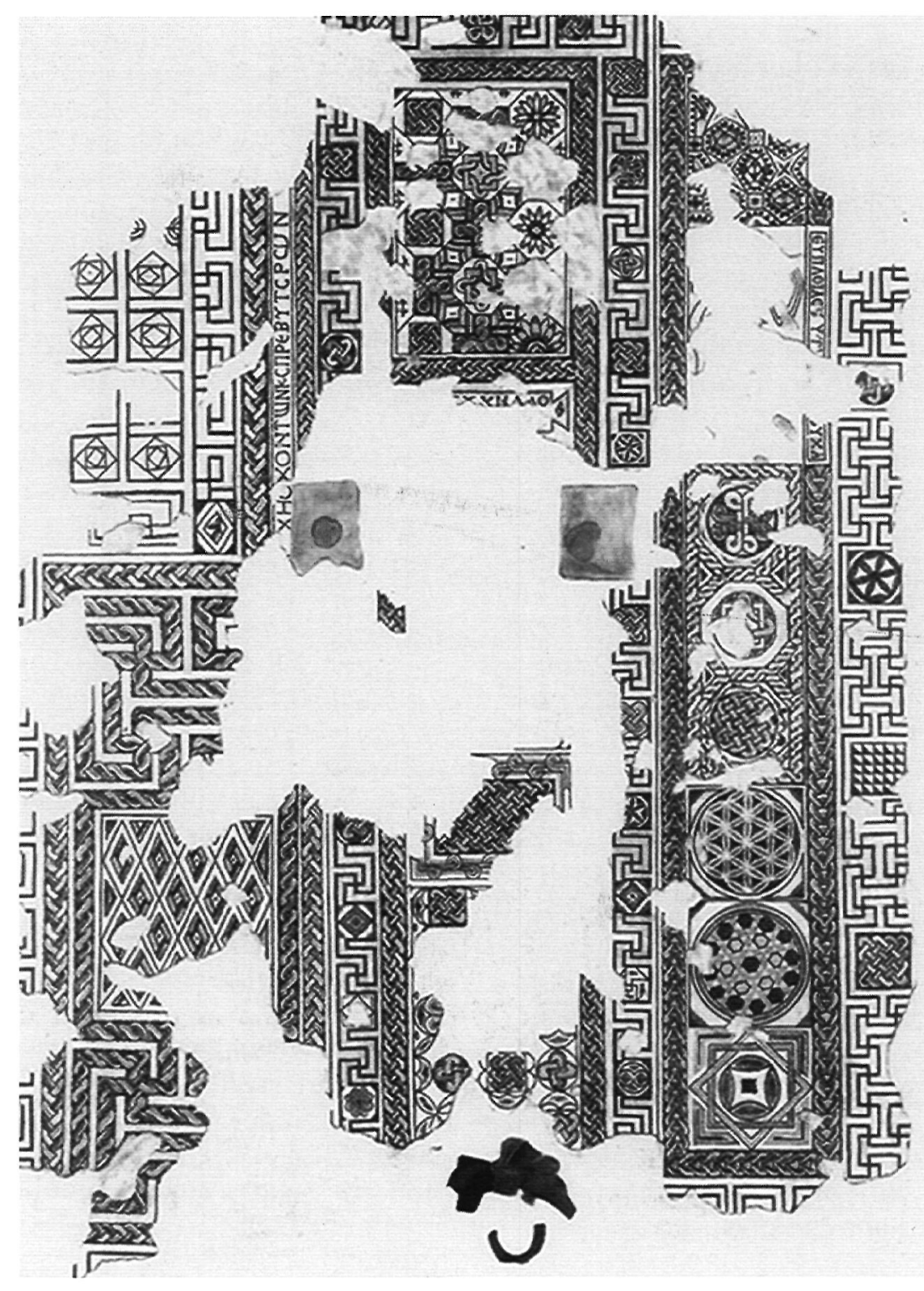

Fig. 11. Planta del paviment de mosaic de la basílica d'llici (Deutsches Archäologisches Institut). (Ruíz Roig, 2001, 41).

blanc com a fons, negre blau a les línies dominants del dibuix, i groc clar, groc fosc, rosat, siena rostida, i gris a la resta dels plànols (Ruíz Roig, 2001, 42), el mosaic presenta una organització en tres franges longitudinals de diferent amplària i decoració (Fig. 11) (Ibarra Ruíz, 1906, 123-124; De Palol, 1967, 203-205).

Aquest paviment de mosaic policrom $i$ motius geomètrics i figuratius mostra com a principal característica -segon pilar, juntament amb l'absis, que va fer suposar que es tractés d'un edifici religiós- tres inscripcions sens dubte compostes per "un mosaicista que debió de copiar a su albedrío un cartón en el que sólo veía dibujos y cuya lectura desconocía" (Llobregat, 1985, 442) i que, escrites en un grec relaxat en quant a l'ortografia es refereix, varen fer canviar el 1907 l'opinió inicial d'Eugène Albertini sobre si l'edifici no devia ser una sinagoga en comptes d'una basílica cristiana.

Seguint els excavadors Pere Ibarra (1906, 124) i Eugène Albertini $(1907,123)$, la primera inscripció, ubicada a la dreta de l'hemicicle i escrita d'oest a est (Fig. 12), se'ns mostra dins un doble rectangle i incompleta a l'inici, afectada per la destrucció que ocupa tot el centre del mosaic, i realitzada amb tessellae blaves, més petites que les de la resta del mosaic, sobre un fons blanc. Es distanciava 2,25 m del costat nord i 6,50 de l'oest, i el 1905 conservava una longitud de $2,94 \mathrm{~m}$, amb una amplada de $18 \mathrm{~cm}$ i una mida de 12 (P. Ibarra) 


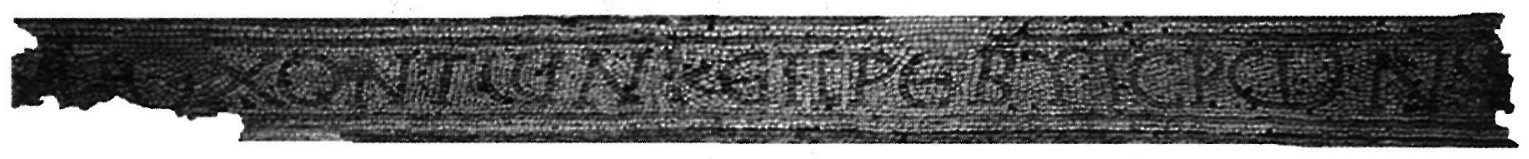

Figura 12: Primera inscripció del mosaic de la basílica (Fotografia de l'autor).

ó 13 (E. Albertini) $\mathrm{cm}$ per a les lletres. En conservava 21, acabant amb una panela en forma d'heura."[...] XHOXONT $\omega \mathrm{N}$ KE. IIPEBYTPCN".

Pere Ibarra va traduir-la com "Adoratorio de los Presbíteros" (1906, 124), mentre que Eugène Albertini $(1907,123)$ va llegir un primer

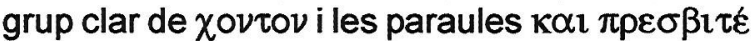
pov deformades. Acceptat aquest $\pi \rho \varepsilon \sigma \beta \imath \tau \varepsilon \rho \rho \nu$ (Frey, 1936, n.663), Antonio Ferrua $(1942,145)$ -seguint Eugène Albertini- va llegir " $\alpha \rho] \chi 0 v \tau \omega v$ $\kappa \varepsilon(\kappa \alpha \imath) \pi \rho \varepsilon(\varsigma) \beta v \tau \varepsilon \rho \omega \nu$ ", i Helmut Schlunk $(1948,340-341)$ va indicar la possibilitat que es tractés dels archontes i els presbyteroi, fent, doncs, referència la inscripció al lloc reservat en l'edifici per als seus lectus o cadires enfront de la congregació -idea que recull Pere de Palol (1967, 202)-. Però posteriorment (Schlunk i Hauschild, 1978, 145-146; Schlunk, 1982, 62) va argumentar que les primeres lletres no podien fer referència als archontes, lectura pendent d'aclarir -...icheochontes (Schlunk i Hauschild, 1978, 146)-, mantenint, però, la hipòtesi de la ubicació de les cadires a aquesta zona malmesa. D'altra banda, José Lafuente $(1948,393)$ va suggerir un ús profà de l'edifici i una lectura: "Aquí la voz de los conductores (dirigentes o capitanes de buques) y ancianos (o decanos)".

La segona inscripció es troba, segons els excavadors (Ibarra Ruíz, 1906, 125; Albertini, 1907, 122-123), emmarcada dins una tabula ansata (Fig. 13) i escrita de nord a sud, és a dir, orientada cap a la porta i d'esquenes a l'absis. Estava realitzada amb les mateixes tessellae blaves més petites que les de la resta del mosaic, i també sobre un fons blanc, però amb tessellae grogues dins els espais buits de

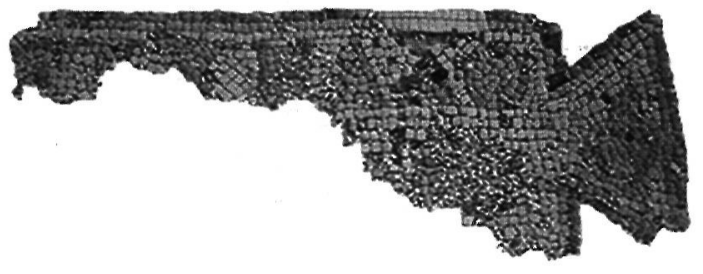

Figura 13: Segona inscripció del mosaic de la basílica (Fotografia de l'autor). les lletres. Es trobava a $3,25 \mathrm{~m}$ de l'absis, amb unes mides d'1,8 m per $25 \mathrm{~cm}$ d'amplada, i el 1905 constava de dues línies amb vuit lletres intactes per a la superior. "IIP [...] $€$ YXH $\Lambda$ AO".

Pere Ibarra $(1906,125)$ suggereix "Adoratorio del Pueblo", i Eugène Albertini $(1907,123)$ indica que "la lecture non douteuse est $\pi \rho[0 \sigma] \varepsilon v \chi \eta ் ~ \lambda \alpha{ }^{\prime}$. Si interpretem eixa proseuché com a "lloc d'oració" (Frey, 1936, núm.662) -o directament com a "sinagoga" (Ferrua, 1942, 145)-, i lao com a un derivat de

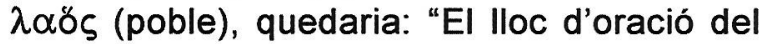
poble de...", faltant només probablement el topònim (Schlunk, 1948, 339), i servint per identificar l'edifici amb una sinagoga. José Lafuente (1948, 394), dins l'explicació d'edifici comercial, entén un acusatiu i tradueix "(Lugar) para la demanda al pueblo", suposant una segona línia que diguera "y para la oferta al mismo". I finalment, mantenint "El lloc d'oració", Helmut Schlunk $(1982,62)$ relaciona la inscripció amb la posterior col-locació de pilastres i cancells, i suposa una finalitat de separació entre els fidels i la zona de l'altar.

La tercera i última inscripció (Ibarra Ruíz, 1906, 124; Albertini, 1907, 123-124), ubicada dins una sanefa a $6,73 \mathrm{~m}$ del costat nord i a $2,10 \mathrm{~m}$ del costat est, és a dir, de l'absis, n'estava escrita d'est a oest (Fig. 14) i també realitzada amb les mateixes tessellae blaves més petites que les de la resta del mosaic, sobre un fons blanc, i amb tessellae grogues dins els espais buits de les lletres. Relacionada amb un motiu perdut que suggeria "un mar agitado" (Ibarra Ruíz, 1906, 123), tenia el centre destruït i presentava $1,80 \mathrm{~m}$ de llargària, $12 \mathrm{~cm}$ d'amplada, i una mida de les lletres de $9 \mathrm{~cm}$; i el 1905 conservava senceres 15 lletres

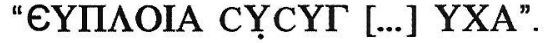

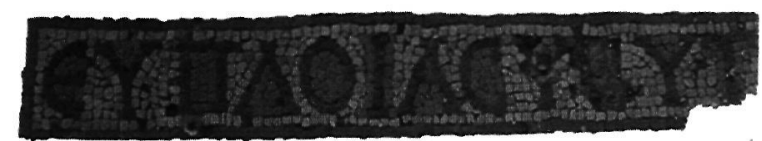

Figura 14: Tercera inscripció del mosaic de la basílica de l'Alcúdia (Márquez i Poveda, 2000b, 190). 
Pere Ibarra suggereix el significat de "Buen viaje" (1906, 125). Eugène Albertini (1907, 123-124) indica com després del mot $\varepsilon u ́$ $\pi \lambda$ oi $\alpha \zeta$ s'identificaven les lletres $v \sigma v, \pi, v$, acabant pel grup $v \chi \alpha$. Antonio Ferrua (1942,

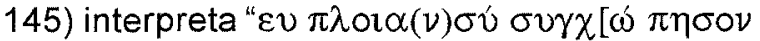
$\varepsilon \mu \eta ́$ ] $v \chi \eta$ " mentre que José Lafuente (1948,

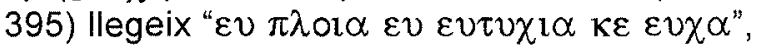
i ho interpreta com a "Felices navegaciones, muy buena suerte y honores", Helmut Schlunk $(1948,341)$ recull el "Buen Viaje" de Pere Ibarra, però posteriorment (Schlunk y Hauschild, 1978,145$)$ va suposar " $\varepsilon v \pi \lambda$ ol $\alpha \sigma v$ ( $\sigma \circ 1) \varepsilon v \tau v \chi \eta \sigma(\varepsilon v \tau v \chi \omega \sigma)$ ", i finalment (Schlunk, 1982, 64) proposà la transcripció "EYП $\Lambda$ OIA . CYEY•TY [...] OYXA", traduint "un feliz viaje te (deseamos) (...)", i comprovant que aquell "mar agitado" de què parlava Pere Ibarra $(1906,123)$ era la representació d'un vaixell, del qual es conservava "una parte de la vela, un trozo de la popa de la nave y, por debajo y a la derecha, las olas del mar, entre las que se conoce un pez al que le falta la cabeza" (Schlunk, 1982, 64).

Últimament (Márquez i Poveda, 2000, 189-192), s'ha suggerit que en aquest motiu es representés el cicle de Jonàs, identificant eixe "pez al que le falta la cabeza", per característiques i posició, amb el monstre marí-cetusque engoleix al protagonista, i s'ha relacionat amb una zona de pas cap a un possible baptisteri.

\section{ANTIGUES I NOVES INTERPRETACIONS: SINAGOGA VERSUS BASÍLICA}

Amb les inscripcions arribariem al que ha esdevingut el gran problema de la investigació sobre aquest edifici pavimentat de mosaic de l'Alcúdia d'Elx; la seua adscripció crono-cultural com a lloc de culte cristià o jueu. O el que resulta el mateix, Sinagoga versus Basílica, sens dubte el problema historiogràfic més tractat del jaciment i amb més repercussions a nivell general. En aquest treball, però, ens limitarem a presentar les teories més utilitzades per donar una datació i explicació a la basílica d'llici, tractant doncs d'aportar una mica de claredat a un edifici que, com veiem en el següent quadre sinòptic, ha tingut moltissimes propostes cronològiques i d'adscripció religiosa -ací en presentem 26-; la majoria, malauradament, només basades en la recerca de paral.lels estilístics del mosaic i/o de les inscripcions.
L'eix de la discussió ha tractat sobre les tres inscripcions en grec relaxat del mosaic, que varen fer canviar l'opinió inicial d'Eugène Albertini sobre si l'edifici devia ser una sinagoga en comptes d'una basílica cristiana. Polèmica -no tancada definitivament des de llavors- per a la qual pot consultar-se la primera impressió dels excavadors (Ibarra Ruíz, 1906; 131-132; Albertini, 1907, 124-125) mentre que les opinions més argumentades es troben a Helmut Schlunk (1948; 1952; 1982, i 1978 amb Theodor Hauschild, amb bibliografia), i a Pere de Palol (1967).

\begin{tabular}{|c|c|c|}
\hline \multicolumn{3}{|c|}{ PROPOSTES SOBRE L'ADSCRIPCIO CRONO-CULTURAL DE L'EDIFICI. } \\
\hline AUTOR (i primera menció). & SINAGOGA & BASÍLICA \\
\hline \multicolumn{2}{|l|}{ P.IBARRA (1906) } & IV $/ V \cdot V I$ \\
\hline \multicolumn{2}{|l|}{ E.ALBERTINI (1906a) } & VI-VII \\
\hline E.ALBERTINI (1907) & Vi-VII & \\
\hline \multicolumn{2}{|l|}{ V.LAMPEREEZ (1908) } & ¿? \\
\hline \multicolumn{2}{|l|}{ J.PUIG I CADAFALCH (1909) } & Vi-VII \\
\hline H.KOHL - K.WATZINGER (1916) & $v-v_{1}$ & \\
\hline \multicolumn{2}{|l|}{ H.LECLERCQ (1922) } & IV \\
\hline \multicolumn{2}{|l|}{ J.R.MÉLIDA (1935) } & $V-V I$ \\
\hline J.B.FREY (1936) & V1 & \\
\hline \multicolumn{2}{|l|}{ P.BATLLE (1947) } & $\mathrm{V} \ldots$ \\
\hline H.SCHLUNK (1947) & IV & VI-VII \\
\hline J.LAFUENTE (1948) & IN & \\
\hline \multicolumn{2}{|l|}{ H.SCHLUNK (1952 i 1982) } & IV-VII \\
\hline P.DE PALOL (1967) & IV & $\mathrm{V}$ \\
\hline A.RAMOS (1972) & $\mathrm{N}$ & VII \\
\hline ELLOBREGAT (1975b) & N & V-VIII \\
\hline R.RAMOS FERNANDEZ (1975) & $N-V$ & VII \\
\hline J.ORLANDIS (1977) & $\mathrm{N} / \mathrm{VH}$ & \\
\hline L.GARCIAA IGLESIAS (1978) & N.V & VII \\
\hline \multicolumn{2}{|l|}{ H.SCHLUNK y Th.HAUSCHILD (1978) } & IV-VII \\
\hline \multicolumn{2}{|l|}{ M. Sotomayor (1979) } & IV... \\
\hline \multicolumn{2}{|l|}{ E.LLOBREGAT (1985) } & $\mathrm{IV}-\mathrm{V} \| \mathrm{I}$ \\
\hline \multicolumn{2}{|l|}{ R.RAMOS FERNÁNDEZ (1995a) } & $\| V-V I I$ \\
\hline \multicolumn{2}{|l|}{ A.RAMOS MOLINA (1997) } & IV-VII \\
\hline R.HACHLILI (1998) & $\mathrm{IV}-\mathrm{V}$ & VII \\
\hline \multicolumn{2}{|l|}{ J.C.MÁRQUEZ Y A.POVEDA (2000b) } & IV-VII \\
\hline
\end{tabular}

Si bé la datació al S.IV defensada per Helmut Schlunk el 1947, per paral-lels del mosaic (Schlunk, 1948, 343), ha sigut acceptada per tota la historiografia posterior, no hi ha hagut el mateix quòrum pel que fa al caràcter jueu o cristià, tot i que paradoxalment ha sigut el mateix Helmut Schlunk el millor defensor d'ambdues opcions, primer com a sinagoga i després -un cop vistos els mosaics redescoberts l'any $1947^{28}$ - com a basílica (Schlunk,

\footnotetext{
${ }^{28}$ El primer treball de Helmut Schlunk, Iliurat el 1946 al III Congreso Arqueológico del Sudeste español celebrat a Múrcia l'any següent i publicat el 1948, va basar-se en uns plànols que va enviar-li Pere Ibarra el 1930, i que va dibuixar B. Steinmüller el 1932. En examinar la planta redescoberta per l'excavació d'Alejandro Ramos del 1948, canvià de idea gràcies especialment al motiu marí que acompanyava la tercera inscripció, per al que no va trobar cap paral.lel en sinagogues i si en basíliques (Schlunk, 1952, 182; 1982, 64).
} 
1952). De tota manera, l'opció que defensava una sinagoga -ara quasi oblidada- ha tingut el seu major suport en la lectura i transcripció de dues de les inscripcions -les que abans hem considerats primera i segona-, mentre que aquells que defensaven una basílica cristiana argumentaven les proves documentals sobre l'existència de bisbes de la ciutat als concilis visigots de Toletum, així com -alguns- la possibilitat que hi haguera una seu episcopal anterior, i també l'existència de l'absis.

Pel que fa a la primera inscripció, la que va ser traduïda com "Adoratorio de los Presbíteros" i utilitzada com a prova del seu caràcter religiós i cristià (lbarra Ruiz, 1906, 124), van ser Eugène Albertini primer (1907, 123), però especialment Helmut Schlunk (1948, $340-341$ ), els qui varen indicar la possibilitat que devia tractar-se dels archontes i dels presbyteroi característics de les cerimònies desenvolupades a les sinagogues. Aquest argument es va veure reforçat per la segona inscripció del mosaic, emmarcada en una tabula ansata, amb la interpretació del mot proseuché com "sinagoga" (Ferrua, 1942, 145), i de tota la part conservada com a "La sinagoga del poble de..." (Schlunk, 1948, 339). La idea de Helmut Schlunk dels archontes i presbyteroi va ser recollida per Pere de Palol $(1967,202)$, qui plantejà la possibilitat de combinar ambdues situacions - una sinagoga inicial del S.IV convertida en basílica al S.V-; opció que veritablement va triomfar en la historiografia posterior, especialment pel que fa als excavadors del jaciment (Ramos, 1972; Ramos Fernández, 1975).

Tanmateix, el 1978 Helmut Schlunk i Theodor Hauschild popularitzaren una teoria anterior en favor del cristianisme original de l'edifici (Schlunk, 1952), que no havia gaudit de massa difusió ${ }^{29}$, però que des de llavors ha sigut la majoritària. Argumentaren (Schlunk y Hauschild, 1978, 145-146) que no podia parlarse d'archontes, atès que la lectura ...icheochontes restava pendent d'aclarir -mantenint, però, la hipòtesi de la ubicació de cadires a aquesta zona tan malmesa-, que els presbyteroi podien ser també personatges cristians -com ja s'havia apuntat des de la primera interpretació (Ibarra Ruíz, 1906, 128), i igualment varen trobar paral-lels en altres basíliques paleocristianes per al mot grec proseuché (Schlunk i Hauschild, 1978, 145).

Altrament, la utilització de la llengua grega que va fer suposar que es tractés d'una sinagoga -on són molts els casos constatats per a inscripcions en grec- (Schlunk, 1947; De Palol, 1967), o bé d'una església bizantina S.VI- (Ibarra Ruíz, 1906, 130-132; Puig i Cadafalch et alii, 1909, 295-296), cal emmarcarla dins el context tardà on ja ha sigut destacat eixe caràcter de grecparlants per als protagonistes de les primeres conversions al cristianisme (Arce, 1971, 246; Garcia Iglesias, 1981, 368) -"para servir a una comunidad de habla griega" suposa l'edifici Luís Ángel García Moreno $(1972,134)$-, així com un més que probable origen oriental del cristianisme peninsular (García Iglesias, 1981, 367-368)-, per la qual cosa no resultaria gens antinatural que ens trobàrem davant una església paleocristiana més.

Així doncs, l'opció de defensar una basílica cristiana s'ha imposat en la historiografia, en un procés constant des que el millor defensor de la identificació amb una sinagoga va canviar de bàndol l'any 1952. I així, amb posterioritat a l'última forta argumentació favorable a un caràcter purament cristià (Schlunk i Hauschild, 1978; Schlunk, 1982), no ha tingut continuïtat l'explicació contemporània (Orlandís, 1977, 178) que, en parlar de localitats amb població jueva segons notícies de procedència literària $o$ arqueològica, assenyalava Elche com una d'elles, important comunitat "que tenía una sinagoga desde época romana y de ella nos han llegado tres inscripciones" (Orlandis, 1977, 80). Igualment, només de manera residual es continua defensant l'opció clàssica encunyada per Pere de Palol de suposar inicialment una sinagoga, que es convertiria després en temple cristià (cf. Hachlili, 1998).

Tot i així, malgrat que les últimes investigacions opten per un edifici cristià fundacional -amb una argumentació que aci acceptem i defensem-, inclús amb unes datacions massa reculades (Ramos Fernández, 1995a), la possibilitat que ens trobem davant

\footnotetext{
29 Pere de Palol (1967), que segueix explícitament Helmut Schlunk (1948), desconeix eixa nova interpretació del mateix autor, ja publicada com a notizia feia quinze anys. Tampoc Rafael Ramos $(1975,44)$ no en coneix l'estudi, en parlar el 1975 de la inexistència de noves publicacions referents al mosaic des del 1948. Només Luís A. Garcia Moreno (1972, 134) esmenta aquest article abans que el propi Helmut Schlunk el citara el $1978 \mathrm{i}$ el 1982 , dates a partir de les quals pareix recuperar-se com a bibliografia (vid. Llobregat, 1991, 171, nota 27; Márquez i Poveda, 2000b) o, si més no, es cita com a tal però amb el títol en castellà, una errata causada pel propi Helmut Schlunk el 1982.
} 
un edifici que algun temps funcionés com a sinagoga no pot definitivament descartar-se. Per això, i de nou pels paral lels amb altres inscripcions en sinagogues, hi ha qui manté algun dubte raonable envers la definitiva adscripció cultural de l'edifici, al menys en la seua fase inicial (Llobregat, 1985, 436; Márquez i Poveda, 2000a, 192).

\section{LA NECRÒPOLIS AD SANCTOS ASSOCIADA A LA BASÍLICA.}

L'any 1950 Alejandro Ramos va prosseguir les excavacions que efectuava des de 1948 pels voltants de la basílica, però centrant-se aquest any a l'est de l'edifici absidal, cap al camí que, tallant en dos parts la lloma de l'Alcúdia, conformava l'entrada a sa casa -cami que actualment es pot veure asfaltat-. És a dir, el que seria la part posterior de la basílica, prop de la zona de l'absis. Seguint l'informe d'excavació referent a la campanya de 1950 (Ramos, 1956), veiem com eixe any va descobrir i excavar una necròpolis que considerà visigoda:

"Apenas comenzamos a cavar y a una profundidad de 25 centímetros de la superficie, o sea en pleno nivel agrícola, observamos la aparición de unos huesos, que descubiertos con el cuidado que el caso requería, nos mostraron la existencia de varios esqueletos casi completos, en número de cuatro, orientados de Este a Oeste, más los huesos de las piernas de otro, y todos ellos deteriorados seguramente a causa de las labores agrícolas, dada su proximidad a la superficie, razón por la cual deben haber desaparecido otros esqueletos de esta supuesta necrópolis visigoda (...).

En ninguna de estas sepulturas se han encontrado restos ni huellas de madera, clavos ni otros indicios de cajas o féretros para su enterramiento; es más, las fosas excavadas para inhumar los cadáveres eran de dimensiones reducidas. Este conjunto de observaciones nos hace suponer que los cadáveres, tal vez envueltos en simple sudario, fueron colocados en las fosas y cubiertos de tierra, de forma que probablemente a simple vista pudieran localizarse las sepulturas.

La modestia de estas sepulturas se manifiesta asimismo en sus ajuares, que casi no existían, pues sólo se han encontrado fragmentos de vasijas muy bastas, y tan sólo junto a uno de los cráneos y en el lugar correspondiente a las orejas había unos pendientes en forma de aro y con un adorno perforado de pasta vitrea" (...). "Este reducido número de sepulturas, conservado por hallarse entre árboles viejos, creo son parte de una necrópolis visigoda destruída por las labores agrícolas, necrópolis que corresponde a la última época en que estuvo poblada La Alcudia y que corresponde al tipo de las de Herrera del Pisuerga, Castiltierra y Villel de Mesa, y cuya cronologia se puede calcular que corresponde a los siglos VI-VII después de J.C." (Ramos, 1956, 107).

Apuntem aci la possibilitat de trobar-nos davant una necròpolis tardana intramurs ${ }^{30}$, a la part posterior de la basílica; a la qual només es constataren cinc enterraments -tot i que pareix que n'hi devien haver més-, i que potser fóra una àrea privilegiada d'enterrament per trobarse pròxima a l'absis - ad sanctos-. Les tombes s'hi caracteritzaven per una gran simplicitat, sense "restos ni huellas de madera, clavos ni otros indicios de cajas o féretros para su enterramiento" (Ramos, 1956, 107), mentre que "los esqueletos se hallaban sobre la tierra, en dirección este-oeste, estando la cabeza al este" (Ramos, 1972, 171), pràcticament sense aixovars "pues sólo se han encontrado fragmentos de vasijas muy bastas" (Ramos, 1956, $107)$, sent a més les fosses de reduïdes dimensions.

Pel que fa a la localització, els enterraments d'aquest tipus -al voltant o fins $i$ to dins les esglésies-, resulten d'allò més comú al llarg dels segles IV al VIII, (De Palol, 1967; Puertas, 1975; Ripoll, 1989; Godoy, 1989; 1995) malgrat les prohibicions conciliars existents. Així, respecte a soterrar-se dins les esglésies ${ }^{31}$, el cànon XVIII del provincial Bracarensis Concilium I (Vives et alii, 1963, 75), diu que:

"Item placuit, ut corpora defunctorum nullo modo intra basilicam sanctorum speliantur, sed si necesse est de foris circa murum

\footnotetext{
30 Pareix clara l'existència a llici d'altres dues necròpolis extramurs, al nord $i$ sud, possiblement vinculades amb les vies d'accés a la ciutat (Lorenzo, 2002, 139-152), amb un nombre important d'enterraments i variada tipologia de tombes - una amb tres tipus diferents ben descrits (Ibarra, 1879, 16768), i l'altra també amb tres tipus (Ramos, 1956; 1962)-, que podrien estar transmetent una llarga utilització de les necròpolis.

${ }^{31}$ Contràriament a l'opinió d'algun investigador (cf. Ripoll, 1989,396 ), la disposició pareix fer referència només als àmbits basilicals i no al conjunt de la ciutat com a realitat murallada. Vid. José Vives (et alii 1963, 541), qui transcriu el text, quan en referenciar els temes diu: "Basílica, prohibición de enterramiento".
} 

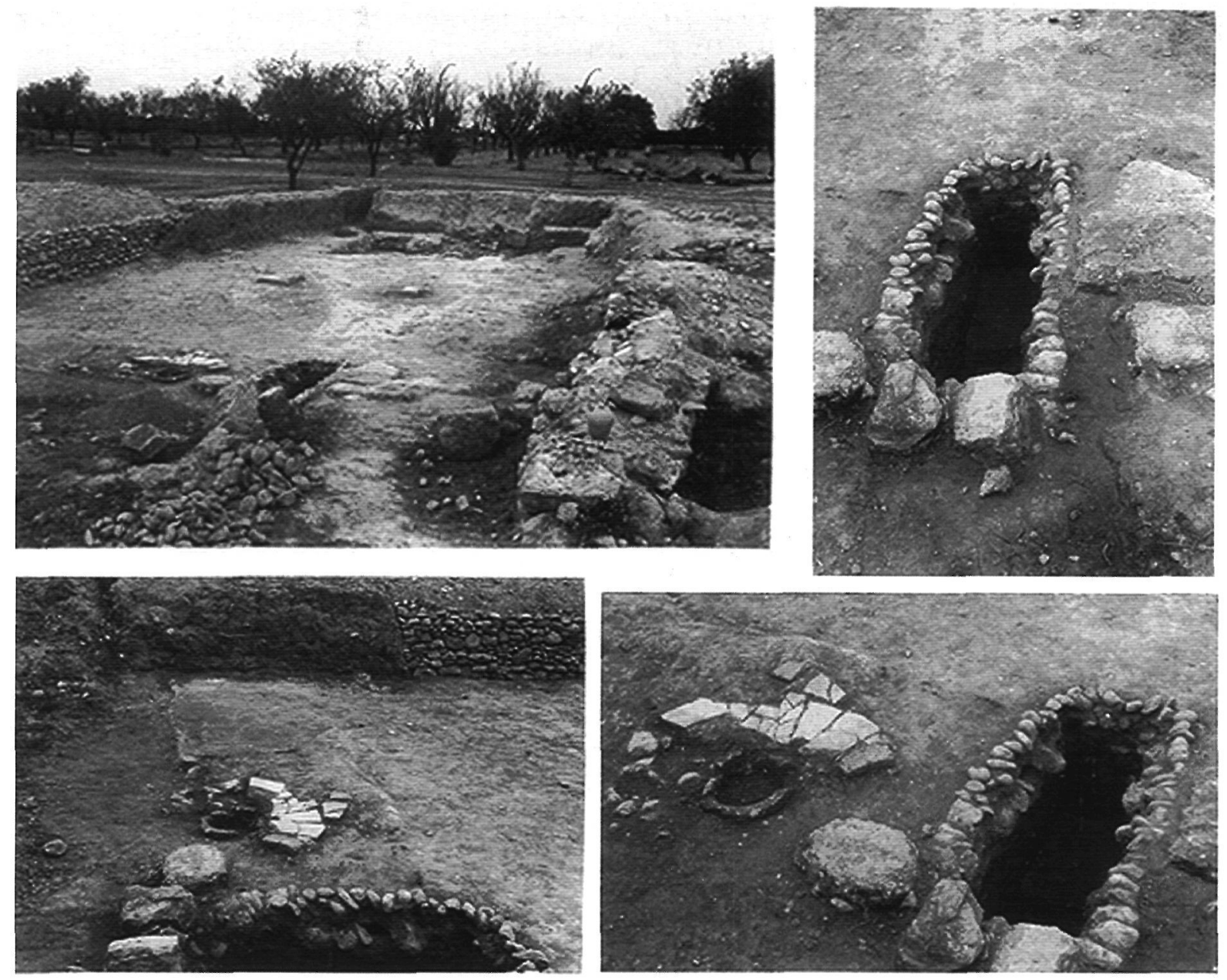

Figura 15: Dalt a l'esquerra es pot veure una fotografia de conjunt de la planta basilical un cop ja retirat el paviment de mosaic, amb les dues pedres encastades i l'absis a l'est al fons, mentre que dalt a la dreta veiem una fotografia de detall de la fossa. A sota tenim dues fotografies que relacionen la fossa amb una curiosa estructura circular envoltada per lloses (Fot.A.Ramos, AFA).

baselicae usque adeo non abhorret. Nam si firmissimum hoc brevilegium (sic) usque nunc retinent civitates, ut nullo modo intra ambitus murorum cuiuslibet defuncti corpus humetur, quanto magis hoc venerabilium martyrum debet reverentia obtinere",

I és ací on aportarem una novetat important pel que fa a aquesta necròpolis dels voltants de la basílica, com és l'aparició d'una tomba que podria trencar el paviment de mosaic a la zona oest de l'edifici (Fig. 15). Aquest enterrament no pareix correspondre a un altre que va ser publicat l'any 1955 per Alejandro Ramos -com a corresponent a la campanya de 1948- clarament ubicat al sud del mosaic ${ }^{32}$. Sinó que aquesta veritable fossa d'enterrament probablement es va descobrir més tard en retirar el paviment de mosaic ${ }^{33}$, tot i que podria relacionar-se amb l'altre soterrament, ampliantse, doncs, cap a l'oest l'àrea de necròpolis que clarament s'estén a l'est de l'edifici, fora, a prop de l'absis.

Helmut Schlunk i Theodor Hauschild $(1978,9$, làm.3) sí que indiquen l'existència de la fossa, tot $i$ que no la comenten, $i$ aixi apareix a la planta amb cotes que varen prendre amb posterioritat de l'extracció del mosaic -no reflectit- $\mathrm{i}$ abans de la data de publicació; és a

32 "Entre los restos de un muro encontrado junto a estos objetos apareció un cráneo humano con el oído derecho pegado al suelo, rodeado de un murete de arcilla, y encima, parte de los huesos correspondientes a los brazos y piernas. Al Norte del cráneo, un círculo de tierra quemada" (Ramos, 1955,133 ). Aquest cercle, ¿podria ser l'estructura circular apreciable a la Fig. 11?

33 Enric Ruiz Roig (2001, 40) indica com el 1965 el mosaic va ser dibuixat per C.Zamora, suposem que amb anterioritat a l'aixecament. És així que aquesta actuació es produiria a finals dels anys seixanta, igual que la troballa d'aquesta fossa atès que les fotografies indiquen la data de 1971. 


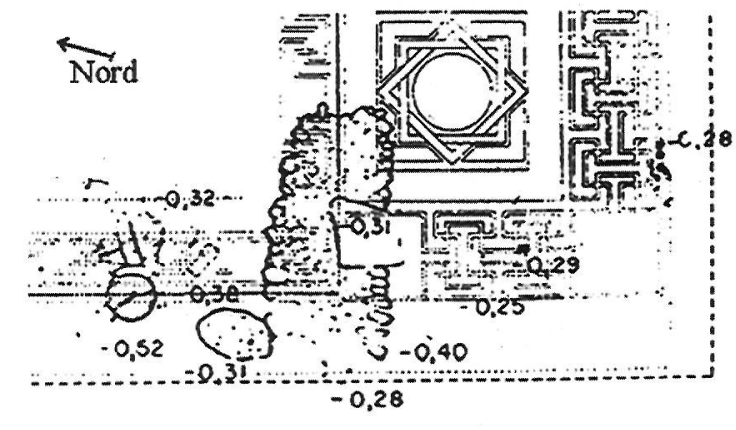

Figura 16: Detall del plànol de Helmut Schlunk i Theodor Hauschild $(1978,9)$

dir, a principis dels anys setanta (Fig. 16). Tenim, doncs, una fossa orientada est-oest -per la forma pareix que amb la capçalera a l'oestexcavada al terra -no sabem si afecta estructures anteriors pre-mosaic- $\mathrm{i}$ amb les parets recobertes de maçoneria. No pareix constatarse cap soterrament, però en qualsevol cas, la qüestió més important que planteja aquesta fossa sens dubte és saber si va trencar el paviment de mosaic, o si bé ens trobem davant una tomba preexistent.

Així, malgrat que la fossa pareix abastar més superfície de la que el paviment de mosaic mostra perduda en la planta del Deutsches Archäologisches Institut de la Fig.11 -i seria, doncs, anterior ${ }^{34}$, segons la planta de Helmut Schlunk i Theodor Hauschild, on s'aprecia perfectament l'existència de la fossa i les diferents lloses immediates al nord -que probablement són les que va reflectir Eugène Albertini (1906b, 337) (Fig.1) i que es veuen perfectament al mapa del Deutsches Archäologisches Institut-, pareix que ens trobem davant la primera possibilitat -un trencament del mosaic-, atès que, tal com s'aprecia en comparar -amb les tres fotografies $i$ els tres plànols a la mà- les plantes conservades del mosaic amb l'extensió ocupada per la fossa, un retall del paviment a eixa zona pareix ben clar. Malauradament, però, no hem trobat res publicat -llevat del mapa de Helmut Schlunk i Theodor Hauschild- sobre aquest sorprenent descobriment i ens movem en el terreny de la semiespeculació, atès que la tomba mai no s'ha relacionat amb el paviment de mosaic -hem dit com probablement es va descobrir quan ja no hi havia paviment-, i les fotografies no són tan precises com es voldria.

No obstant això, és molt possible que ens trobem davant el primer enterrament que trenca el paviment de mosaic de la basílica d'llici, i podríem pensar que ubicat a una zona marginal de l'edifici -al final, allunyada de l'absis-. Dins el terreny de la pura especulació, potser ens trobem davant d'alguna mena d'estranya expansió - no explicada-d'aquesta església cap a l'oest -com podria deduir-se de l'actual planta conservada (vid. Ramos Molina, 1997)-, i de l'aprofitament d'eixa nova zona sacra com a ampliació de la necròpolis constatada a l'est de l'edifici. En tot cas, en l'estat actual de la investigació, els problemes aportats per aquesta tomba pareixen superar clarament a les respostes.

Malgrat tot, d'aquesta necròpolis ad sanctos dels voltants de la basílica, i al marge d'apuntar l'anòmala posició dels cossos amb el cap a l'est i les cames a l'oest, una orientació minoritària tant pel que fa a la conca del Vinalopó (Segura i Tordera, 1999, 535) com de manera general -per exemple només suposa l' $1,71 \%$ de les 485 tombes excavades del cementiri meridional d'Empúries (Nolla, 1995, 103)-, només pareix raonable suggerir -com ja va suposar Alejandro Ramos $(1956,107)$ una més gran extensió per a aquesta necròpolis, la qual sens dubte va ser molt afectada per les activitats agrícoles al llarg de la primera meitat del S.XX, atès que les poques tombes conservades es trobaven protegides per eixos arbres vells que impedirien el pas de la reixa al llarg dels anys, mentre que l'escassa profunditat $-25 \mathrm{~cm}$ - en què van aparèixer, sens dubte facilitaria la destrucció de la resta d'enterraments.

D'aquesta manera, sense més informació que l'escassa oferta pel seu excavador, i sense conèixer clarament posicions i relacions entre les tombes, les mides d'algunes i les relacions estratigràfiques de totes; aixi com desconeixent els aixovars amb un cert detall, les posicions $i$ les característiques físiques dels cadàvers, resulta molt difícil oferir, ni tan sols de manera aproximada, una datació que siga mínimament rigorosa, i haurem de basar-nos per força en paral-lels i consideracions/datacions genèriques. Així, només es pot assegurar que la necròpolis no correspon al tipus de les d'Herrera del Pisuerga (Palència) o Castiltierra (Segòvia), com va mantindre Alejandro Ramos (1956, 107), sinó que resulta totalment diferent a

\footnotetext{
34 Tanmateix, ho considerem una errada en l'elaboració de la planta, atès que es marca perfectament un cantó de la tercera banda del mosaic que, a la resta de mapes publicats, no apareix tan clarament identificat, i que actualment no es conserva.
} 
aquestes grans extensions de tombes. Amb la qual cosa ens quedem sense l'únic argument cronològic -segles VI-VII- esgrimit pel seu excavador, tot $i$ que de manera genèrica ha estat ubicada entre els segles V-VIII (Gutiérrez Lloret, 1988, 333; Segura i Tordera, 1999, 534). Pel que fa als paral-lels -pobres-, aquestes tombes de fossa simple ${ }^{35}$ les veiem paregudes al Subtipus 1.A sense coberta de la conca del Vinalopó, dels segles V-VII (Segura i Tordera, $1999,535)$, o a la major part de les tombes del Muntanyar, sense aixovar ni cobertes (Bolufer, 1986). Pel que fa a la tomba que pareix tallar el mosaic, les fosses delimitades per tovots $i$ maçoneria a altres necròpolis properes es desenvolupen al llarg dels segles IV-VI (Soriano, 1989, 410). D'altra banda, atès que la inhumació com a ritual d'enterrament es generalitza a la Península Ibèrica des del S.III, i que les fosses excavades directament sobre el terra $\mathrm{i} / 0$ amb taüts de fusta abracen del $\mathrm{S}$.I al S.VII (Laiz i Berrocal, 1995, 163), pareix que una datació tardana es veu reforçada, però sense que, a l'estat actual de la investigació, una major precisió resulte possible (vid. Ripoll, 1996).

Altrament, hi ha alguna informació addicional provinent del que tradicionalment s'ha considerat material arqueològic per excel-lència, la ceràmica. Així doncs, tenim com "próximo al lugar donde fue hallado el busto de la Dama, o sea al noroeste, y a $100 \mathrm{~m}$. de aquel lugar", en un lloc on "se hallaban casi al descubierto restos de paredes" (Ramos, 1966 , 75) -al Sondeig IV, nivell II- Alejandro Ramos $(1966,75)$ va trobar, a una perforació del signinum que formava el terra d'una habitació, un conjunt format per "dos pondus de barro cocido, una anforita y cuatro vasijas incompletas, todas ellas de barro basto de color amarillento. Junto a estas vasijas un esqueleto humano", Eixa anforita ${ }^{36}$ associada a un esquelet, anys després, va ser interpretada provinent d'un context funerari, amb "indudables paralelismos con las del interior de la Península Ibérica de cronología visigoda" (Gisbert, 1986, 207), amb una datació al S.VII -sense descartar, però, la segona meitat del S.VI- de plena influència visigoda -o potser bizantina-. Si aquesta troballa correspon a un enterrament d'època visigoda relativament pròxim a la zona de necròpolis de la basílica ${ }^{37}$, podríem estar davant d'un soterrament que, en perforar el signinum, fou protegit de la reixa $i$ evità ser destruït per les "labores agrícolas (...), razón por la cual deben haber desaparecido otros esqueletos de esta supuesta necrópolis visigoda (...)" (Ramos, 1956, 107), I per tant podria tractar-se'n d'un testimoni que estigués reflectint una gran extensió per a la necròpolis ad sanctos associada a la basílica, però a l'actual estat de la investigació només se'n pot plantejar la possibilitat.

\section{LA DATACIÓ DE LA BASÍLICA, UN PRO- BLEMA NO RESOLT}

Per al cas d'llici, i amb posterioritat a les primeres versions -diguem-ne apologètiques (Garcia Iglesias, 1981, 365-366, amb bibliografia)- que suposaven una antiguitat apostòlica a l'arribada del cristianisme (Flórez, 1751, 234-235; Ibarra, 1879, 233), les diferents propostes efectuades al llarg del S.XX han estat generalment relacionades -i sovint basadesamb la datació de la basílica. La tendència ha sigut, des de la primera interpretació que suposava una basílica cristiana -i per tant una comunitat- al S.IV (Ibarra Ruíz, 1906), la de defensar una extraordinària -i mai no provadaantiguitat per a l'edifici.

I podria dir-se que aquesta idea s'ha convertit en una veritable tradició historiogràfica

35 Tot $\mathrm{i}$ que a les memòries publicades no es diu res al respecte (Ramos, 1955; 1962), més bé tot el contrari -"(..) sin que hayamos encontrado vestigio alguno de sepulturas construidas con piedras" ( Ramos, 1970, 70)-, Juan Carlos Márquez i Antonio Poveda $(2000 b, 195)$-potser per comunicació personal dels excavadors-diuen com pels voltants de la basilica "se hallaron sepulturas en fosa y sarcófagos monolíticos con cubierta a dos aguas y elementos de adorno personal en los enterramientos" (La cursiva és meua). Podria ser una errada deguda a l'existència de sarcòfags per a les dues necròpolis extramurs (Ibarra, 1879, 167-168; Ramos, 1956, 112; 1962, 91; 1970, 64), que hagen sigut transpaperats.

36 "Botella de cuerpo cilindrico con dos asas. Cuello con paredes de curva cóncava que se une al cuerpo en curva continua. Las asas son arqueadas, bastante salientes y de sección ovalada, no pudiéndose asegurar si llevaría moldura al cuello a la altura de su unión con estas. El cuerpo es cilindrico con ligero abombamiento central, y la base ligeramente convexa. (...) Pasta de color ocre blanquecino, aspecto arenoso y desgrasante poco visible. Presenta un leve tratamiento superficial de color similar y bien adherido a la pasta. Está realizado a torno" (Gisbert, 1986, 207). Diàmetre de base $8,5 \mathrm{~cm}$, altura conservada $24,6 \mathrm{~cm}$ i amplada màxima $13^{\prime} 4 \mathrm{~cm}$.

37 Ja que la basilica es troba a $158 \mathrm{~m}$ "al Oeste del punto mismo en que fue hallado el famoso busto" (Ibarra Ruiz, 1906. 121), i l'actual troballa del Sondeig IV va aparèixer "próximo al lugar donde fue hallado el busto de la Dama, o sea al noroeste, y a $100 \mathrm{~m}$. de aquel lugar" (Ramos, 1966, 75). És a dir, a uns 50 ó $60 \mathrm{~m}$ de l'absis. 
al llarg de l'últim quart del S.XX, originada per la suposició de Helmut Schlunk i Theodor Hauschild $(1978,146)$ de què es tractés, ni més ni menys, de la més antiga basílica de la Península Ibèrica. Aquesta idea fou posteriorment recollida -"si nuestra interpretación es correcta, tendríamos en Elche la iglesia cristiana más antigua de la Península" (Schlunk, 1982, 64)- i/o matisada -"és probablement l'església conservada més antiga de la Península" (Barral, 1982, 119); o "la más antigua de las conocidas en la Península Ibérica" (Molina i Poveda, 1995, 152)-. Però, no obstant això, l'últim pas en aquesta línia ha sigut el plantejament interessat ${ }^{38}$ d'una fundació definitiva i precisa per a l'any 322 (Ramos Fernández, 1995a, 1231); datació que serà fermament criticada.

Ara bé, el principal problema que té la investigació moderna, de cara a proporcionar una datació a la basílica d'llici, és la falta d'una estratigrafia fiable que permeta establir unes relacions clares entre estructures i paviments, estructures i estructures, paviments i paviments, i entre els materials apareguts a les estructures o els paviments, que mai no s'ha obtingut al llarg de les diferents excavacions (Ibarra Ruíz, 1906; Albertini, 1907; Ramos, 1955) practicades. Atesa la falta d'una veritable estratigrafia per al conjunt del jaciment, els estudis que puguen realitzar-se sobre l'edifici hauran d'estar basats malauradament només sobre paral-lels constatats en moments i llocs pròxims; i no únicament del mosaic com ha sigut una tradició, sinó també de la planta i d'altres característiques a la llum de les noves informacions que sobre el món de l'arquitectura tardana en tenim cada dia. És així que únicament una revisió amb profunditat dels estudis ja efectuats sobre la sinagoga-basilica, recorrent a les fonts originals i no fent una cita de cita de cita..., podrà aportar una correcta informació sobre aquest tema, rellegint, doncs, antics treballs a la llum de noves preguntes, i relacionant l'edifici amb les últimes aportacions provinents d'altres parts del jaciment.

Per això obrirem ací un tema que, de forma gratuïta -quan els grans estudis efectuats sobre el mosaic comencen a envellir, i es converteixen en una espècie en extinció pel que a consulta bibliogràfica es refereix - $s$ 'ha volgut tancar amb una argumentació que, inconsistent, no mereix posar punt i final a un problema històric que tan profundament ha sigut tractat:
"Durante los actuales trabajos de consolidación de muros de la citada construcción, aunque a causa de las lluvias, se produjo el desprendimiento de una pequeña parte del revoco de cal de la sillería en un punto del ángulo noreste del edificio, desprendimiento que permitió la afloración de los huesecillos de una paloma y de dos monedas: 1 . Constantino Magno y 2. Constantino II: (...) Follis. 318-319 d.J.C. (...) Follis.322d.J.C.

El hallazgo se produjo en el área de pastoforías o sacristías, en la zona de correspondencia al diaconicón, en el sillar de esquina noreste del edificio, sillar que forma la segunda hilada del ángulo interior de la construcción, que fue rebajado en sus caras lateral-exterior e inferior, sellada la cavidad con una laja de piedra de $20 \times 17 \times 6 \mathrm{~cm}$ y después revestido de estucado.

Este conjunto material, monedas y restos de paloma, probablemente aluda a un depósito fundacional situable en el año 322 , que consecuentemente daría una fecha asociable a la construcción de la basílica de llici durante la época de Constantino I y que, además, también confirmaría su condición de basílica cristiana anulando la hipótesis referida a una sinagoga judía que tardíamente se transformó en basílica" (Ramos Fernández, 1995a, 1231). (La cursiva és meua).

Segons l'anterior afirmació de Rafael Ramos, eixe conjunt monetari de dues monedes es converteix probablement en un dipòsit fundacional situable a un any i que conseqüentment dona una data precisa, associable al nivell fundacional d'una construcció. És a dir, "allò probablement situable és conseqüentment associable". Però en primer lloc falta argumentació en favor d'un dipòsit fundacional -no totalment acceptat per altres investigadors ${ }^{39}$ - que, tot i l'atractiu de la idea, no es converteix en tal pel fet d'aparèixer "a causa de las lluvias" dues monedes i alguns ossos a un arrebossat de calç, o bé a la cavitat que aquest arrebossat pareix que camuflava a un carreu foradat, segons la

\footnotetext{
38 "Fue siempre el interés local, las rivalidades de pueblos y de diócesis, lo que sostuvo el interés por los falsos hallazgos, aunque estos se refiriesen a puntos de historia religiosa. (...). toda la trama se dirige en realidad siempre a prestar antigüedad ilustre a determinados lugares (...)" (Sánchez Alonso, 1944, 15-16)

39 "(...) proporciona una datación post quem y, en opinión de su excavador (...) una datación precisa (322 dC) si aceptamos considerar los restos como una deposición relacionada con la erección del edificio" (Márquez i Poveda, 2000b, 192).
} 


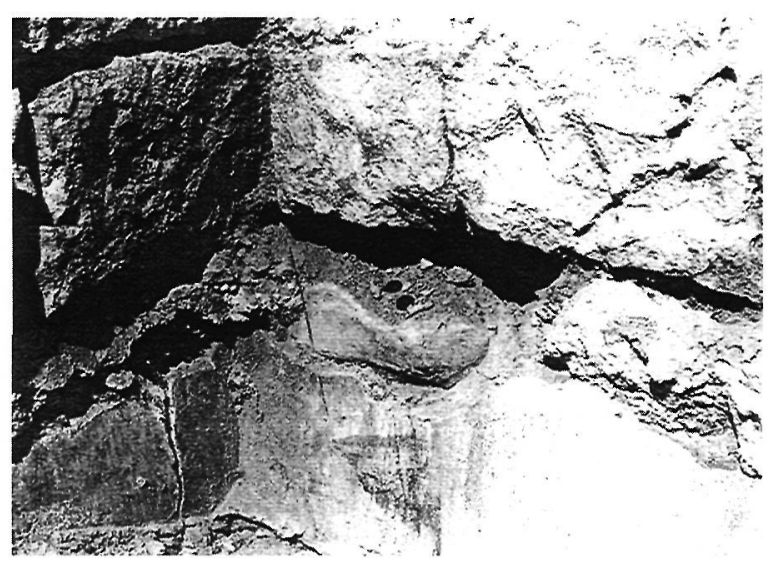

Figura 17: Detall del mur on va aparèixer el conjunt de monedes i ossos (Ramos Fernández, 1995a, 1232).

descripció. La qualitat de les fotografies (Fig. 17), tampoc no aclareix la situació.

I si la datació d'aquest conjunt és discutible per quant la pervivència o perduració de les monedes romanes del S.IV és un fet constatat per als segles posteriors (Marot, 1997 a i b), molt més ho és el fet d'associar eixe dipòsit a una fase constructiva d'una basílica de la qual no coneixem en realitat quins murs corresponen a quina època o paviment, atès que hi ha moltes fases i no és clara la relació entre els elements constructius.

Així doncs, no només és discutible el fet de trobar-nos davant un dipòsit fundacional per a la basílica sinó que la seua datació a la primera meitat del S.IV és una acció arriscada per la pròpia perduració del monetari romà del $\mathrm{S} . \mathrm{IV}$, tot i que en aquest cas pareix que ambdues monedes no circularen gaire ${ }^{40}$. En conseqüència, si volem anar més enllà de dir que un dels murs situats més a l'est de l'absis -és a dir, fora de l'estança pavimentada amb el mosaic ${ }^{41}$ - està obligadament construït després de l'any 322 , estarem desvirtuant una datació exclusivament post quem, atès que "(...) en el cas de desconèixer el context arqueològic, és quasi impossible determinar la cronologia dels dipòsits formats per moneda del segle IV, que, com s'ha demostrat i degut al seu manteniment en la circulació, poden ser ocultats en qualsevol moment posterior a la data d'emissió de la moneda més tardana del conjunt" (Marot, 1997a, 1003).

I per això, no resulta clar ni és cosa segura que la basílica fóra construïda al primer quart del S.IV, com pareix acceptar-se a publicacions posteriors ${ }^{42}$. No només perquè la datació absoluta que es presenta no resisteix la crítica, sinó bàsicament perquè falten dades per a poder sostindre una datació o una altra, pel greu desconeixement que envolta l'edifici i les seues característiques constructives, així com per la inexistència de qualsevol tipus d'informació estratigràfica que permeta, sens cap mena de dubte, defensar una possibilitat o una altra. Així doncs, igual que al llarg dels anys des d'aquell descobriment el 1905, la cronologia de l'edifici resulta insegura i no es poden fer més que hipòtesis de treball, com la que ara suggerirem -basant-nos a les característiques de l'edifici, a les pròpies del cristianisme, entès com a fet social, i al context de la seua constatació a les ciutats mediterrànies de la Hispania tardoromana-. Aquesta hipòtesi, però, a l'estat actual de la investigació, encara ha de romandre obligatòriament dins el terreny de la pura especulació.

Una major o menor antiguitat del cristianisme a llici encara no pot ser discutida científicament, atesa la falta de testimonis, tant materials com documentals. Tanmateix, resulta ser una ciutat costanera mediterrània, amb

40 Les dues monedes a què es fa referència són en realitat
dos nummi, dels anys 319 i 321 , recentment catalogats per
Juan Manuel Abascal Palazóna una obra que encara no ha
vist el llum i que suposa un actualitzat corpus numismàtic de
l'Alcúdia:
"A-0315. CONSTANTINO. Nummus. ARELATE, of. $1^{\circ} .319$
d.C. A.-. IMP CONSTAN-TINVS AVG. Busto con casco con penacho y lanza sobre hombro derecho, a derecha.

R.-. VICTORIAE LAETAE PRINC PERP. Dos Victorias de pie y enfrentadas, sosteniendo entre ambas un escudo sobre altar, con la inscripción VOT/PR.

Exergo: PARL 4'36/19/5 RIC VII, 192+nota. (...).

A-0316. CONSTANTINO II. Nummus. AQVILEIA, of. $3^{\circ} .321$ d.C.

A.-. CONSTANTINVS IVN NOB C. Busto laureado y con coraza, a derecha.

R. -. CAESARVM NOSTRORVM. Corona de laurel, conteniendo la leyenda VOTN.

Exergo: ‘AQT ${ }^{\bullet} 20 / 19 / 12$ RIC VII, 96+nota. (...)"

Segons una informació inèdita que he d'agrair a l'amabilitat de Juan Manuel Abascal, actualment se sap com ambdues monedes es caracteritzen per pràcticament no haver circulat. A priori açò podria reforçar una reculada datació per a la col-locació al mur, però la manca de dades obliga a la prudència.

41 Un mur que només modernament (Ramos Fernández, 1995a; Ramos Molina, 1997) s'ha relacionat amb la basílica, i que segons la major part dels autors no pertany a l'edifici (vid. De Palol, 1967, 65).

42 Vid. A. Ramos Molina $(1997,46)$, qui va més enllà i sentencia taxatiu com "Actualmente, la cronología de esta construcción no plantea ninguna duda", D'altres investigadors, menys lligats al jaciment, postulen com "(...) en la vecina llici existía tempranamente una importante comunidad cristiana que, hacia finales del primer cuarto del siglo IV dC, ya parece disponer de un aula o iglesia" (Márquez i Poveda, 2000a, 179-180). 
importants relacions comercials marítimes al llarg dels segles III-IV (Márquez i Molina, 2001), i res millor per a la propagació del cristianisme que els nuclis urbans costaners del sud-est Peninsular, amb grups de població oriental seguidors d'altres religions mistèriques de la Mediterrània oriental (García Iglesias, 1981, 368). Aquesta última suposició podria perfectament aplicar-se a llici-Portus llicitanus, si suposem l'existència de colònies comercials orientals i la conseqüent comunicació d'idees al llarg del Baix Imperi (García Moreno, 1972); és a dir, un bon ambient per a la propagació del cristianisme ${ }^{43}$. Però suposar una datació tan primerenca com el 322 per al primer edifici cristià a $/ l i c i$, només nou anys després de l'Edicte de Mediolanum i la legalització del culte, sembla excessiu inclús sense la critica a la feblesa d'aquesta datació.

Primer de tot cal precisar com, si bé el 313 amb l'Edicte de Mediolanum el culte cristià fou autoritzat, no seria fins l'any 395 que el codex Theodosianus implantàel cristianisme com a única religió pública, restant els cultes anteriors sotmesos a una simple tolerància (Arce, 1982, 137-138), i quan el cristianisme podria tindre ja un major pes a Hispania que el paganisme (Garcia Iglesias, 1981, 376), si bé probablement reduït a l'àmbit urbà. És aixi que, si bé al llarg del S.IV el cristianisme -com a fenomen religiós, però també social i econòmic- progressivament va obrir-se pas, més que probablement encara era molt minoritari "minoria urbana de clase alta" (Llobregat, 1977, 106) - i no va acabar d'assentar-se com a única religió sinó al llarg dels segles següents (García Iglesias, 1981).

Aixi doncs, no obstant ser possible una ràpida arribada del cristianisme a llici i inclús allò que ens interessa- una reculada cristianització de grups socials amb capacitat de construir un edifici religiós, caldria relativitzar eixe prompte, atesa la dificultat de suposar que l'any 322 (Ramos Fernández, 1995a, 1231; Ramos Molina, 1997, 46) o "hacia finales del primer cuarto del siglo IV dC" (Márquez y Poveda, 2000a, 179-180), la minoria cristiana d'llici tingués no un lloc modest de culte, sinó tota una església amb un ric paviment de mosaic que probablement rivalitzaria amb els que encara eren vigents temples pagans. Aquest paviment el farem servir com a prova que done suport a una datació més tardana de l'edifici que -si bé totalment susceptible de crítica i modificació- ens pareix més correcta i científicament defensable.
La imatge catastrofista de ruptura amb el món urbà al S.III i conseqüent crisi generalitzada a tots els àmbits -amb invasions bàrbares, etc.-, que feia de l'Antiguitat Tardana un moment de decadència, des de començaments de l'últim quart del $S . X X$ ha sigut progressivament superada i contextualitzada (vid. Arce, 1978; 1993; Barral, 1982, Garcia Moreno, 1999), apuntant-se ara no tant cap a una extinció - no constatada- de la ciutat romana, sinó a un profund i progressiu canvi pel que fa a la seua concepció, amb un nou enfocament que entén i interpreta l'Antiguitat Tardana com a "civilització eminentment urbana" (Barral, 1982, 108); on seran moltes les ciutats que al llarg dels segles posteriors gaudiran de moments de prosperitat i esplendor urbana, especialment pel que fa a la zona del sud-est Peninsular (Gutiérrez Lloret, 1999).

Així, al S.IV la vida urbana es conserva -sempre que es conserve la ciutat, és clar-, combinada per l'aristocràcia amb la vida en les sumptuoses villae que tant han cridat l'atenció de la investigació arqueològica tradicional, i que en són constatades per a les rodalies d'llici (Ibarra, 1879; Ramos Fernández, 1977), i parcialment conegudes pel que fa als seus mosaics (Ibarra, 1879, 178-202), l'únic element conservat-físicament o mitjançant els dibuixos d'Aurelià Ibarra-, i conseqüentment l'única base que ha pogut donar una cronologia malauradament només basada en criteris estilístics; que per tant a més de no massa fiable resulta hieràtica, només corresponent als moments creacionals dels mosaics. En qualsevol cas, tot i desconèixer l'evolució posterior d'aquest sistema de villae constatat en la centuriatio, $\mathbf{i}$ per tant del poblament tardà d'aquestes terres, la datació oferta per a la majoria dels mosaics "de la zona rural de Illici" correspon als segles III-IV (Ruíz Roig, 2001, 115-116), precisada cap a la segona meitat del S.IV pel que fa al cas dels d'Algorós (Mondelo, 1985, 141).

I precisament els paral-lels més immediats que trobem per a la composició del paviment de la basilica són eixa sèrie de mosaics existents a les villae del Camp d'Elx, i especialment un procedent de la villa d'Algorós (Ibarra, 1879, làm.XXI), "con una disposición

\footnotetext{
43 Una cristianització primerenca també es defensa per a la conca mitjana del Vinalopó, on s'apunta que hi haja una comunitat cristiana amb "un buen número de miembros" al $S$ IV pels voltants del Monastil, relacionada amb dos o potser quatre sarcòfags i amb un edifici religiós dels segles IV-V (Márquez i Poveda, 2000a, 177-179).
} 
idéntica" segons Helmut Schlunk, que va fer-li suposar (Schlunk, 1948, 342-343) que el paviment de la basílica fóra "labrado por artífices que pertenecían todavía a la misma escuela o tradición". Idea mantinguda a les publicacions posteriors, especialment des què Pere de Palol $(1967,197)$ diguera que el paviment de la basilica no pot diferenciar-se de la resta de testimonis del conjunt de la ciutat en el mateix moment del S.IV. Aquest mosaic d'Algorós, per al que podriem suposar una cronologia si més no similar al paviment de la basilica, té defensada una datació "por el estudio de los esquemas y motivos decorativos" possiblement cap a la segona meitat del S.IV (Mondelo, 1985,141), lluny doncs de la data del 322.

"(...) No hay, por tanto, ninguna necesidad de reconocer en el mosaico de la sinagoga influencias extranjeras, bizantinas, ni de asignarle una fecha tardía. La semejanza con los mosaicos de la misma Elche es tan grande, que podemos atribuir nuestro suelo a un taller romano-tardío y una fecha mucho más temprana de lo que se ha creído hasta ahora. (...) podemos decir que no distarán mucho de los demás de Elche y que su erección debió tener lugar en la época bajorromana, aproximadamente el siglo IV" (Schlunk, 1948, 342-343) ${ }^{44}$.

Pere de Palol $(1967,207-209)$ va fer seua la proposta de Helmut Schlunk, defensant-ne una datació al S.IV mitjançant l'estudi de diversos paral-lels formals per al paviment de mosaic; precisada, però, cap a la segona meitat del S.IV (De Palol, 1967, 205-206) segons l'anàlisi del motiu central -"Nos parece del todo evidente la fecha del siglo IV, y muy posiblemente en su segunda mitad, para este pavimento, que además está perfectamente dentro de las normas del mosaico hispánico del momento" (De Palol, 1967, 210)-. I inclús, indirectament, reduint-la a finals del S.IV (De Palol, 1967, 344) en comparar el mosaic d'llici amb l'anomenat d'Urcinus (Logroño). Posteriorment, Alejandro Ramos $(1974,100)$ va admetre que "sólo parece bastante claro que el mosaico, por su técnica, parece ser del siglo IV o tal vez de principios del V".

D'altra banda, la implantació cristiana a la ciutat no pot ser entesa fora del marc de la transformació de la ciutat al llarg del Baix Imperi (Barral, 1982, 109), i és ací on podrem aportar alguna altra informació referent a la basílica, bàsicament pel que fa a la seua ubicació diguem-ne allunyada de l'espai central de la lloma de l'Alcúdia, a una zona marginal. Així, d'una manera general sabem que, quan amb el desenvolupament del cristianisme s'aixequen esglésies a les ciutats, en alguns casos s'aprofiten edificis públics que ja no eren d'utilitat (Février, 1974, 115-117; García Moreno, 1977, 314-315), però també s'hi installen sovint en barris destruïts i/o abandonats (Barral, 1982, 113), amb una alienació barrejada d'espais públics i privats.

"Car les esglésies que s'anaven construint a ciutat, segons la demanda dels grups cristians, ho foren amb un finançament difícil de precisar a Hispània, $i$ en qualsevol cas, segons l'espai urbà disponible. En efecte, no costa pas el mateix comprar un terreny al bell mig de la ciutat que en un barri perifèric, prop de les muralles. Sovint aquest darrer espai devia estar encara lliure, sense construir, o hom hagué de destruir solament cases de poc cost. Aquestes són les raons, més que no pas les defensives, que feren construir les esglésies prop de les muralles, i llur situació a la ciutat determinà sovint la forma irregular d'alguns monuments" (Barral, 1982, 114-115).

Aquest podria ser el cas de la basílica d'llici, construïda "en un solar donde se constata la existencia previa de pavimentos de opus caementicium y restos de diferentes fases de época romana que aparecen parcialmente bajo el nivel de construcción de este ambiente rectangular" (Márquez i Poveda, 2000b, 192), segons les descripcions efectuades pels dos primers excavadors ${ }^{45}$ (Ibarra Ruíz, 1906, 125; Albertini, 1906b, fig. 2 ; 1907, 121 i 126-127). Tindríem, doncs, com les primeres comunitats cristianes d'llici, varen poder comprar o adquirir una zona ${ }^{46}$-ja fóra un solar, casa o cases abandonades $\mathrm{i} / 0$ per enderrocar, etc. - $\mathrm{i}$

\footnotetext{
44 Aquesta argumentació de Helmut Schlunk és la que ha triomfat en la historiografia sobre $/ / i c i$, i la trobem literalment copiada en R.Ramos Fernández $(1975,242 ; 1984,16)$ o en A.Ramos Molina (1997, 45), qui equivoca l'ordre de la numeració romana i diu "No hay, por tanto, ninguna necesidad de reconocer en el mosaico influencias extranjeras. Podemos decir que su cronologia encaja con los demás mosaicos de Elche y que su erección tuvo lugar en la época bajorromana, en el siglo VI".

45 "Il semble donc qu'antérieurement à la proseucha juive existait en cet endroit un bâtiment romain, dont le sol est en partie conservé sous la mosaïque" (Albertini, 1907, 126-127).

46 "En aquest procés resulta difícil conèixer el paper que tingué l'especulació sobre l'espai urbà, o quin era l'espai disponible en un moment determinat. També és difícil d'imaginar com eren finançats els monuments i quina era la part de la comunitat cristiana, que no sabem on habitava ni com esta distribuïda dins la ciutat" (Barral, 1982, 129-130).
} 
construir-hi una església tan luxosa -paviment almenys-com les més importants villae properes del moment, cosa que probablement compensà la quasi segura ubicació marginal dins l'esquema urbà, característica típica de les primeres esglésies -a finals del S.IV o principis del S.V- per raons econòmiques i religioses sovint al costat de les muralles-, excepte en els casos de substitució de temples pagans al centre de la ciutat (Barral, 1982, 129).

Aquesta datació a la segona meitat del S.IV ${ }^{47}$-o principis del S.V $V^{48}$-, que continua donant una molt ràpida cristianització del paisatge urbà d'llici, tot i ser feble no està en desacord amb allò que sabem -poc-del conjunt basilical, ni pel que fa als paral-lels formals del paviment de mosaic (Schlunk, 1948, 342-343, De Palol, 1967, 210) -que la recolzen-, o pel possible motiu del cicle de Jonàs ${ }^{49}$, ni pel que fa a la posició marginal de l'edifici (Barral, 1982) i la seua llarga utilització -constatada en les nombroses reparacions del paviment (Albertini, 1906b; 1907, 120)-. I tampoc no contradiu la informació post quem proporcionada pel conjunt monetari que -no ho oblidem- no podem relacionar clarament amb la planta estricta de la basílica.

És així que pren consistència la possibilitat $-d$ 'antic esmentada en diversos articles i monografies- de trobar-nos davant un temple cristià construït a la segona meitat del S.IV. Inclús, més a prop dels moments finals del segle que culminarien l'any 395 amb la implantació del cristianisme com a única religió pública, o millor encara a principis del S.V, una cronologia que semblaria més concordant amb la situació del conjunt d'Hispania als segles IV-V.

D'altra banda, tot i que s'allunya dels objectius d'aquest article, resulta obligat esmentar, ni tan sols superficialment, alguna cosa sobre les últimes interpretacions de l'evolució d'aquest emblemàtic edifici al llarg dels segles de l'Antiguitat Tardana. És així que molt recentment (Márquez, 2000; Márquez i Poveda, 2000a i b) -i en bona part per paral-lels amb el proper jaciment d'El Monastil (Elda)s'ha plantejat que podríem trobar-nos davant uns testimonis de l'existència a finals del S.VI -és a dir, sota el domini i la influència bizantinsd'un edifici religiós amb un altar de tipus oriental a l'absis i amb columnes de basa poligonal. Situació que, de comprovar-se, probablement estaria transmetent una certa preocupació per les autoritats i oligarquies de l'llici bizantina per arreglar, embellir o "posar al dia" el temple, amb unes reformes -nova taula d'altar, potencials columnes poligonals-que potser poden relacionar-se amb algunes de les reparacions efectuades sobre el paviment (vid. Albertini, $1906 \mathrm{~b} ; 1907,120$ ), tot i que perduda la basa poligonal i, a l'estat actual de la investigació, malauradament no es pot anar més enllà de l'especulació.

També al S.VII s'han datat una sèrie de reformes i afegits practicats a la basílica d'llici, que potser estiguen donant-nos proves d'una possible gran reforma visigoda de la ciutat. Tindríem, doncs, com al S.VII l'antiga basílica veuria una important reforma -podríem dir quasi més litúrgica que no arquitectònica-, encastant al paviment de mosaic dues pedres foradades a les quals és possible s'ubicaren dos espigons, per a aguantar un sistema de cancells que reforçaria la separació entre fidels i zona de l'altar-potser anteriorment marcada només per la segona inscripció del mosaic (Schlunk, 1982, 62)-. És així que, al precari estat actual de la investigació, pareix possible que amb l'arribada dels visigots a finals del primer quart del S.VII, les noves autoritats escometeren una sèrie de reformes urbanístiques a llici que, especialment -o bé en són les úniques constatades - varen afectar a allò religiós; com ara afegint cancells -i/o finestrals- a l'església de paviment de mosaic, o amortitzant una superfície -parcialment ja espoliada- al centre de la lloma -zona del suposat forum-per tal de conformar una gran plaça sobre la que destacaria només un antic temple, reconvertit ara en la segona església constatada a l'Alcúdia, que també podria presentar una incorporació de cancells (Molina i Poveda, 1995).

D'altra banda, respecte d'aquell mur irregular que -probablement en un moment posterior-va dividir la sala en dos, cobrint el mosaic amb una perfecta direcció oest-est, i sobrepassant-lo $1,5 \mathrm{~m}$ fins arribar a $50 \mathrm{~cm}$ del mur de l'absis (Albertini, 1907, 121); o per al potencial baptisteri apuntat per a la zona

\footnotetext{
47 Datació que també ja va apuntar Xavier Barral $(1982,119)$ quan considerava la basílica d'llici probablement la més antiga conservada de la Península, "la qual podria datar de la segona meitat del segle IV",

48 El mosaic "traspasa ya probablemente las lindes del siglo V' diu Pere Batlle $(1947,213)$, suposant-lo semblant al de Santa Maria de Palma (Mallorca), si bé aquest amb moltes representacions figuratives.

49 S'ha suggerit, com hem vist, que l'únic motiu figuratiu, i pràcticament perdut, del paviment de la basílica podria fer referència al cicle cristià de Jonàs, j "apoyaría esa datación general en el siglo IV" (Márquez i Poveda, 2000b, 192).
} 
immediata pel sud-est a l'absis (Márquez y Poveda, 2000b, 194-195); són aspectes per als que malauradament pareix que encara no es pot oferir més informació.

Per a finalitzar, recuperaríem l'anterior argumentació sobre la probable construcció a una àrea marginal dins l'organització de la ciutat per a plantejar la possibilitat de què l'anomenada basílica d'llici -pareix que no l'única església cristiana constatada al jaciment (Ramos Fernández, 1995c, 349-353; Molina y Poveda, 1995, 152)-, ubicada molt prompte en una zona marginal, no fóra, com indirectament s'ha suposat quasi des del moment mateix del descobriment, la futura seu episcopal ilicitana, tot i la riquesa del paviment, sinó tan sols una església més de la ciutat. Potser la primera, sí, però no la més important quan al llarg dels segles V-VI la cristianització de les ciutats siga ja total, i sens dubte els grans temples pagans i la zona del forum - no indubtablement identificada per al cas de l'Alcúdia - tinguen un fort protagonisme pel que fa a erigir-hi una catedral i un conseqüent palau episcopal. És a dir, quan es produïsca l'autèntica i definitiva cristianització del paisatge urbà.

Així doncs, potser els anys vinents noves i desitjables excavacions efectuades a la lloma de I'Alcúdia donen com a resultat el descobriment $i$ estudi de l'important conjunt episcopal que, més que probablement, va tindre l'llici tardana, potser que des d'una data més reculada del que sovint s'ha pensat. Sens dubte, amb aquesta $i$ altres investigacions sobre el fenomen de la cristianització del paisatge urbà de la ciutat, i la seua evolució al llarg dels segles de l'Antiguitat Tardana, podria retre's un merescut homenatge a l'emblemàtica figura del recentment desaparegut Enric Llobregat i Conesa, un dels investigadors que més hores hagen dedicat a l'estudi de l'llici paleocristiana i l'autor de les paraules amb què presentàvem aquest treball que, humilment, voldríem dedicar a la seua memòria.

\footnotetext{
Roberto Lorenzo de San Román

Passeig de Fora Muralla, 12

17004 Girona

robisand@hotmail.com
}

\section{BIBLIOGRAFIA}

ABAD, L., GUTIÉRREZ LLORET, S. i GAMO, B., 2000: "La Basílica y el Baptisterio del Tolmo de Minateda (Hellín, Albacete)", Archivo Español de Arqueologia, LXXIII, 193221.

ALBERTINI, E., 1906a: "Rapport sommaire sur les fouilles d'Elche (Espagne)", Comptes rendus de l'Académie des
Inscriptions, 611-620

ALBERTINI, E., 1906b: "Fouilles d'Elche", Bulletin Hispanique, VIII, n. 4, 333-362.

ALBERTINI, E., 1907: "Fouilles d'Elche (Suite et fin)», Bulletin Hispanique, IX, n.2, 109-127.

ARCE MARTINEZ, J., 1971: "Conflictos entre paganismo y cristianismo en Hispania durante el s.IV", Príncipe de Viana, 124-125, 245-255.

ARCE MARTÍNEZ, J., 1978: "La crisis del siglo III en Hispania y las invasiones bárbaras", Hispania Antiqua, VIII, 257269.

ARCE MARTÍNEZ, J., 1982: El último siglo de la España romana: $284-409$, Madrid.

ARCE MARTÍNEZ, J., 1993: "La ciudad en la España tardorromana: ¿Continuidad o discontinuidad?": Ciudad y comunidad civica en Hispania (siglos II y III después de J.C) (Madrid, 1990), 177-186. Collection de la Casa de Velázquez, 40, Madrid.

BARRALALTET, $X$, 1982: "Transformacions de la topografia urbana a la Hispània cristiana durant l'Antiguitat Tardana", II Reunió d'Arqueologia Paleocristiana Hispànica (Montserrat, 1978), 105-132, Barcelona.

BATLLE HUGUET, P., 1947: "El arte paleocristiano", Ars Hispaniae, II, Historia Universal del Arte Hispánico, 183223, Madrid.

BOLUFER MARQUÉS, J., 1986: "La necròpolis del Muntanyar", Xàbiga, 1, Homenatge a Godofredo Cruanyes Sigues, 109-126.

CABROL, F.(Ed.), 1922-1948: Dictionnaire de l'archéologie chrétienne et de liturgie, tom 5, vol.I, i tom 14, vol.II, Paris.

CASTAÑO GARCÍA, J., 2002: Els germans Aurelià i Pere Ibarra. Cent anys en la vida cultural d'Elx (1834-1934), Alacant.

FERRUA, A., 1942: "Inscripciones griegas y judías", Vives, $\mathrm{J}$.: Inscripciones cristianas de la España romana y visigoda. Barcelona.

FÉVRIER, P.A, 1974: "Permanence et héritages de l'Antiquité dans la topographie des villes de l'Occident durant le Haut Moyen Age", Topografia urbana e vitta cittadina sull'alto medievo in Occidente. $X X \mid$ Settimani di studio del Centro italiano di studi sull'alto medievo (Spoleto, 1973), 41-138, Spoleto.

FLÓREZ DE SETIÉN HUIDOBRO, H., 1751: España Sagrada, Theatro geographico-historico de la lglesia de España. Origen, divisiones, y límites de todas sus Provincias. Antiguedad, traslaciones, y estado antiguo y preferente de sus sillas, en todos los Dominios de España y Portugal. Con varias dissertaciones criticas, para ilustrar la Historia Eclesiástica de España. Tomo VII, de las Iglesias sufraganeas antiguas de Toledo: Acci, Arcavica, Basti, Bearia, Bigastro, Castulo, Compluto, Dianio, Elotana, Ilici, Mentesa, Oreto, y Osuna, segun su estado antiguo, Ed. Antonio Marín, Madrid.

FREY, J.B., 1936: Corpus Inscriptionum ludacarum, Roma

GARCÍA IGLESIAS, L., 1978: Los judios en la España antigua, Madrid.

GARCIAA IGLESIAS, L., 1981: "Paganismo y cristianismo en la España romana", La religión romana en Hispania (Madrid, 1979), 365-379, Madrid.

GARCÍA MORENO, L.A., 1977: "La cristianización de la topografía de las ciudades de la Península lbérica durante la Antigüedad Tardia", Archivo Español de Arqueología, L, 311-321.

GARCÍA MORENO, L.A., 1999: "La ciudad en la Antigüedad Tardía (siglos V-VII)", Acta Antiqua Complutensia, 1. Complutum y las ciudades hispanas en la Antigüedad Tardia, $7-24$. 
GISBERT SANTONJA, J., 1986: "Las cerámicas de cronología visigoda en las necrópolis del País Valenciano", Il Coloquio sobre Cerámica Medieval del Mediterraneo Occidental (Toledo, 1981), 207-215, Madrid.

GODOY FERNÁNDEZ, C., 1989: "Arquitectura cristiana y litúrgia. Reflexiones en torno a la interpretación funcional de los espacios", Espacio, Tiempo y Forma, II, 355-387.

GODOY FERNÁNDEZ, C., 1995) Arqueología y liturgia. Iglesias hispánicas (siglos IV al VIII), Col-lecció Publicacions de la Universitat de Barcelona, 12 Barcelona.

GUTIÉRREZ LLORET, S., 1988: "El poblamiento tardorromano en Alicante a través de los testimonios materiales. Estado de la cuestión y perspectivas", Arte y Poblamiento en el SE Peninsular durante los últimos siglos de civilización romana: Rafael Méndez Ortiz in memoriam, Antigüedad y Cristianismo, Monografías históricas sobre la Antigüedad Tardia, V. 323-337.

GUTIÉRREZ LLORET, S., 1996: La Cora de Tudmir: de la antigüedad tardia al mundo islámico. Poblamiento y cultura material, Collection de la Casa de Velázquez, 57 , Madrid-Alacant

GUTIÉRREZ LLORET, S., 1999: "La ciudad en la Antigüedad Tardía en el sureste de la Provincia Carthaginensis: la reviviscencia urbana en el marco del conflicto grecogótico", Acta Antiqua Complutensia, I. Complutum y las ciudades hispanas en la Antigüedad Tardía, 101-128.

HACHLILI, R., 1998: Ancient Jewish Art and Archaeology in the Diaspora. Collecció Handbuch der Orientalistik, 1. Der Nahe und Mittlere Osten, 35. Leiden.

IBARRA MANZONI, A., 1879: Illici, su situación y antigüedades. llustrada con 25 laminas, conteniendo la reproducción de 237 monumentos antiguos descubiertos casi en su totalidad, y dibujados por el mismo autor. Ed. Antonio Reus. Alacant. Ed.facsimil 1981.

IBARRA MANZONI, A., 1889: "La situación de Illici. Nuevos descubrimientos", El Archivo. Revista literaria semanal, tomo III, 209-214. Ed. Facsimil, 1988.

IBARRA RUIZ, P., 1905: "El cristianismo en I/lici. Descubrimiento de la planta de una iglesia cristiana en la loma de la Alcudia junto á Elche", Revista de la Asociación Artístico-Arqueológica Barcelonesa, IV, 912-917.

IBARRA RUIZ, P., 1906: "Antigua basílica de Elche", Boletín de la Real Academia de la Historia, XIXL, 119-132.

IBARRA RUIZ, P., 1926: E/che, materiales para su historia. Ensayo demostrativo de su antigüedad e importancia histórica, Cuenca.

KOHL, H, i WATZINGER, K., 1916: Antike Synagogen in Galilaea, Leipzig

LAFUENTE VIDAL, J., 1948: "La supuesta sinagoga de Elche", Archivo Español de Arqueologia, LXXIII, 392-399.

LAIZ, M.D. i BERROCAL, M.C., 1995: "Elementos para la datación cronológica de la necrópolis paleocristiana de San Antón en Cartagena", IV Reunió d'Arqueologia Paleocristiana Hispànica (Lisboa, 1992), 163-172, Barcelona.

LAMPÉREZ ROMEA, V., 1908: Historia de la Arquitectura Cristiana Española en la Edad Media. Madrid. Valladolid Ed.facsimil 1999.

LECLERCQ, H., 1907: Manuel d'Archéologie chrétienne depuis les origines jusqu'an VIIle siècle, París.

LLOBREGAT CONESA, E.A., 1975b: "Los orígenes y el final del Obispado de Elche", Revista de l'Institut d'Estudis Alacantins, XIV, 45-59 (Ilucant, 401-406)

LLOBREGAT CONESA, E.A., 1978: "La antigua sede episcopal ilicitana y sus testimonios arqueológicos", Festa d'Elig, Homenaje a Pedro Ibarra Ruiz, 23-28 (llucant, 415-419)
LLOBREGAT CONESA, E.A., 1985: "Las Epocas paleocristiana y visigoda", Arqueologia del País Valenciano: panorama y perspectivas. Annex de Lucentum. Alacant. (llucant, 433-452).

LLOBREGAT CONESA, E.A., 1991: "De la ciudad visigótica a la ciudad islámica en el este peninsular", La ciudad islámica. Ponencias y comunicaciones, 159-188, Zaragoza

LORENZO DE SAN ROMÁN, R., e.p.: L'Alcúdia d'Elx a l'Antiguitat Tardana. Anàlisi Historiogràfica i Arqueológica de l'llici dels segles $V$-VIII, Universitat d'Alacant

MAROT SALSAS, T., 1997a: "Un aspecte de la circulació monetària a la Península lbèrica en època tardorromana: el comportament anòmal dels AE2", Hispània i Roma d'August a Carlemany. Homenatge a Pere de Palol, Vol.2, Annals volum XXXVII, 991-1009.

MAROT SALSAS, T., 1997b: «Aproximación a la circulación monetaria en la Península Ibérica y las Islas Baleares durante los siglos $V$ y VI: la incidencia de las emisiones vándalas y bizantinas», Revue numismatique, 157-190.

MÁRQUEZ VILLORA, J.C., 2000: "Mesas polilobuladas de la tradición oriental en la Península Ibérica: Entre la religión y el comercio", V Reunió d'Arqueologia Paleocristiana Hispànica (Cartagena, 1998), 519-527, Barcelona

MÁRQUEZ, J.C. i MOLINA, J., 2001: El comercio en el territorio de llici: epigrafía, importación de alimentos y relación con los mercados mediterráneos, Alacant.

MÁRQUEZ, J.C. i POVEDA, A.M., 2000a: "Espacio religioso y cultura material en Elo (ss.IV-VII dC)", V Reunió d'Arqueologia Paleocristiana Hispanica, (Cartagena, 1998), 177-184, Barcelona.

MÁRQUEZ, J.C. i POVEDA, A.M., 2000b: "Espacio religioso y cultura material en Ilici (ss.IV-VII dC)", V Reunió d'Arqueologia Paleocristiana Hispànica, (Cartagena, 1998), 185-198, Barcelona

MÉLIDA ALINARI, J.R., 1935: "El arte romano cristiano", R.Menéndez Pidal (Dir.), Historia de España, II, España Romana, Madrid

MOLINA, J. i POVEDA, A.M., 1995: "EI nivel de abandono de un sector del foro de Ilici", XXIII Congreso Nacional de Arqueología (Elx, 1994), 141-154.

MONDELO PARDO, R., 1985: "Los mosaicos de la villa romana de Algorós (Elche)", Boletín del Seminario de Estudios de Arte y Arqueologia, LI, 143-155

NOLLA BRUFAU, J.M., 1995: "Els cementiris tardo-antics de la Neàpolis emporitana", IV Reunió d'Arqueologia Paleocristiana Hispànica (Lisboa,1992), 99-105, Barcelona.

ORLANDIS ROVIRA, J., 1977: Historia de España. La España visigótica. Gredos, Madrid.

PALOL SALELLAS, P. de., 1967: Arqueología cristiana de la España romana. Siglos IV-VI, Madrid-Valladolid.

PARIS, P., 1907: "Promenades Archeologiques en Espagne. Elche", Bulletin Hispanique, IX, 317-334.

POVEDA NAVARRO, A., 1988: El poblado íbero-romano de "El Monastil" (Elda, Alicante). Introducción HistóricoArqueológica, Elda.

PUERTAS TRICAS, R., 1975: Iglesias hispánicas (siglos IV al VIII). Testimonios literarios, Col-lecció Temas de Arte, Madrid

PUIG i CADAFALCH, J., DE FALGUERA, A. i GODAY, J. 1909: L'arquitectura romànica a Catalunya. Vol.l. Precedents. L'Arquitectura romana. L'arquitectura cristiana prerromànica, Barcelona, Ed.facsímil 1983.

RAMOS FERNÁNDEZ, R., 1975: La ciudad romana de Illici, Alacant.

RAMOS FERNÁNDEZ, R., 1977: "Las villas de la cen- 
turiación de Illici", Symposion de ciudades augusteas (Zaragoza, 1976), vol.II, 209-214, Zaragoza.

RAMOS FERNÁNDEZ, R., 1984: La Alcudia: Del Eneolítico a la etapa visigoda, Madrid.

RAMOS FERNÁNDEZ, R., 1995a: "Noticia sobre labasílica paleocristiana de Illici", $X X \mid$ Congreso Nacional de Arqueología (Teruel,1991), 1231-1233, Zaragoza.

RAMOS FERNÁNDEZ, R., 1995b: El templo ibérico de la Alcudia. La Dama de Elche, Elx.

RAMOS FERNÁNDEZ, R., 1995c: "Un templo romano de época augustea en La Alcudia de Elche", XXIII Congreso Nacional de Arqueología (Elx, 1994), 349-354, Elx.

RAMOS FOLQUÉS, A., 1952: "La escultura ibérica y las excavaciones de Albertini en LaAlcudia de Elche", Archivo Español de Arqueología, XXV, 1, 119-123.

RAMOS FOLQUÉS, A., 1955: "Elche (Alicante). La Alcudia (Campañas 1940 a 1948)", Noticiario Arqueológico Hispánico, II, 107-133

RAMOS FOLQUÉS, A., 1956: "Memoria de las excavaciones practicadas en La Alcudia de Elche (Campañas 1949 a 1952)", Noticiario Arqueológico Hispánico, III i IV, 102113

RAMOS FOLQUÉS, A., 1962: "Excavaciones en La Alcudia. Memoria de las Campañas 1953 a 1958", Noticiario Arqueológico Hispano, V (1956-61), 91-97.

RAMOS FOLQUÉS, A., 1966: "Estratigrafia de La Alcudia de Elche", Saitabi, XVI, 71-77.

RAMOS FOLQUÉS, A., 1970: Historia de Elche, Elx.

RAMOS FOLQUÉS, A., 1972: "Un cancel visigodo en La Alcudia de Elche", Pyrenae, 8, 167-172.

RAMOS FOLQUÉS, A., 1974: El cristianismo en Elche. Alacant.

RAMOS MOLINA, A., 1997: La Planimetria del yacimiento de La Alcudia de Elche, Alacant.

REYNOLDS, P., 1993: Settlement and pottery in the Vinalopó Valley (Alicante, Spain), a.d. 400-700, British Archaeological Reports Internacional Series, n.588. Tempvs Reparatvm. Oxford.

RIPOLL LÓPEZ, G, 1989: "Características generales del poblamiento y la arqueología funeraria visigoda en Hispania", Espacio, Tiempo y Forma, II, 389-418.

RIPOLL LÓPEZ, G., 1996: "La arquitectura funeraria de Hispania entre los siglos $V$ y VIII: Aproximación tipológica",
Spania. Estudis d'Antiguitat Tardana oferts en homenatge al profesor Pere de Paloli Salellas, Publicacions de l'Abadia de Montserrat, Sèrie II-tustrada, 12, 215-224, Barcelona.

RUIZ ROIG, E., 2001: Los mosaicos de llici y del Portus Illicitanus, València.

SÁNCHEZ ALONSO, B., 1941, 1944 i 1952: Historia de la Historiografía española. Ensayo de un examen de conjunto. 3 vols., Madrid.

SARABIA BAUTISTA, J., 2003: Los elementos arquitéctonicos ornamentales en el Tolmo de Minateda (Hellin. Albacete). Instituto de Estudios Albacetenses "Don Juan Manuel", Albacete.

SCHLUNK, H., 1948: "El arte de la época paleocristiana en el Sudeste Español. La sinagoga de Elche y el martyrium de La Alberca", III Congreso Arqueológico del Sudeste español. (Murcia, 1947), 335-379, Murcia.

SCHLUNK, H., 1952: "La Sinagoga di Elche e il martyrium di La Alberca", Rivista di Archeologia Cristiana, Anno 28, 34, 182-184

SCHLUNK, H., 1982: "Las conexiones históricas del cristianismo hispánico a través de la iconografía", // Reunió d'Arqueologia Paleocristiana Hispànica - IX Symposium de Prehistoria i Arqueologia Peninsular, (Montserrat, 1978), 55-70, Barcelona.

SCHLUNK, H. I HAUSCHILD, T., 1978: Hispania Antiqua. Die Denkmäler der frühchristlichen und westgotischen Zeit, Madrid.

SEGURA, G. i TORDERA, F., 1999: "La Antigüedad Tardía en la cuenca del río Vinalopó (Alicante): El panorama funerario de los siglos V-VII dC.", XXIV Congreso Nacional de Arqueología, (Cartagena, 1997), vol.IV, 531542, Murcia.

SORIANO SÁNCHEZ, R., 1989: "La Necrópolis de la Boatella: Elementos para su cronologia", Saguntum, 22, 393-411.

SOTOMAYOR MURO, M., 1979: "La Iglesia en la España romana", Historia de la iglesia en España, vol. l, La Iglesia en la España romana y visigoda (siglos I. VIII), p. 1-400, Madrid

VIVES, J., MARIN, T. i MARTÍNEZ DIEZZ, G., 1963: Concilios visigóticos e hispanorromanos, Barcelona-Madrid. 